\title{
DIVERSITY, PHYLOGENY AND BIOGEOGRAPHY OF THE SOUTH AMERICAN 'CARDIOMYINE' RODENTS (HYSTRICOGNATHI, CAVIOIDEA) WITH A DESCRIPTION OF TWO NEW SPECIES
}

\author{
by MARÍA E. PÉREZ ${ }^{1,2,3}$ D , CECILIA M. DESCHAMPS ${ }^{4}$ and MARÍA G. \\ VUCETICH ${ }^{5}$ \\ ${ }^{1}$ Current address: Museo Paleontológico Egidio Feruglio, Av. Fontana 140, Trelew, U9100GYO, Chubut Argentina; mperez@mef.org.ar \\ ${ }^{2}$ Field Museum of Natural History, Chicago, IL USA \\ ${ }^{3}$ Consejo Nacional de Investigaciones Científicas y Técnicas (CONICET), Buenos Aires, Argentina \\ ${ }^{4}$ División Paleontología Vertebrados, Museo de La Plata, CIC Provincia de Buenos Aires, Paseo del Bosque s/n, 1900, La Plata, Argentina; ceci@fcnym.unlp.edu.ar \\ ${ }^{5}$ División de Paleontología Vertebrados, Museo de La Plata, UNLP, Paseo del Bosque s/n, B1900FWA, La Plata, Buenos Aires, Argentina; \\ vucetich@fcnym.unlp.edu.ar
}

Typescript received 2 June 2017; accepted in revised form 15 August 2017

\begin{abstract}
Cardiomyine' rodents are extinct large terrestrial Caviidae closely related to capybaras, that inhabited large parts of South America during the middle Miocene and Pliocene. They are mostly preserved as isolated teeth, but also as skull and jaw fragments. Here we revise the taxonomy of this group and describe two new species, each pertaining to one of the two main late Miocene groups, represented by the genera Caviodon and Cardiomys. This suggests that the diversity of 'cardiomyines' was higher than previously thought. Among the specimens studied there are two almost complete skulls; one from the Andalhuala Formation, Catamarca, and the other from the Arroyo Chasicó Formation, Buenos Aires. The first, housed in the Field Museum of Natural History, was originally catalogued as Cardiomys ameghinorum, a common species for the late Miocene of north-western Argentina (NOA), but is here
\end{abstract}

transferred to the genus Caviodon. This is the first mention of the genus for NOA, enlarging its geographical distribution for the late Miocene. The second skull, assigned to Cardiomys sp., is housed in the Museo de La Plata. Furthermore, from the revision of the holotypes of the species of Caviodon (C. multiplicatus, C. bravardi, C. (Lelongia) paranensis, C. angustidens and C. scalai from the Conglomerado osífero of the Ituzaingó Formation; late Miocene, Argentina) we propose their synonymy with the type species $C$. multiplicatus, decreasing the specific diversity in that locality. Finally, our phylogenetic analysis indicates that the species of 'cardiomyines' are paraphyletic, placing them in a basal position among the Hydrochoerinae.

Key words: Hydrochoerinae, 'Cardiomyines', Miocene, Pliocene, South America.
THE family Caviidae is among the most diverse groups of caviomorph rodents and includes three main extant lineages: Caviinae (cuyes or 'guinea pigs'), Dolichotinae (maras), and Hydrochoerinae (capybaras and rock cavies) (Mares \& Ojeda 1982; Woods 1984; Rowe \& Honeycutt 2002; Woods \& Kilpatrick 2005; Pérez 2010; Dunnum 2015).

'Cardiomyines' are extinct Caviidae that inhabited large parts of South America during the middle Miocene and Pliocene (Vucetich et al. 2010; Vucetich \& Pérez 2011; Kerber et al. 2017) and were long considered to be related to the cavies and maras. They are now considered to be more closely related to Hydrochoerinae than to either
Caviinae or Dolichotinae on the basis of phylogenetic analysis (Pérez 2010; Pérez \& Vucetich 2011; Pérez et al. 2014, 2017a; Vucetich et al. 2012, 2015). They were diverse and abundant, large terrestrial rodents apparently not strictly linked to living in association with permanent water bodies as capybaras do ('cardiomyines' are recorded in sediments of different origins; Esteban et al. 2014) and would have reached more than $15 \mathrm{~kg}$ (Vucetich et al. 2015). These rodents had a plesiomorphic dentition within hydrochoerines, characterized by the presence of a $\mathrm{p} 4$ composed of three prisms, the $\mathrm{m} 1-\mathrm{m} 3$ and $\mathrm{P} 4-\mathrm{M} 2$ formed by two prisms, the M3 formed by three to seven main prisms plus a small posterior projection that may 
be present or not, and a palate as broad as that of the living capybara Hydrochoerus hydrochaeris (Kraglievich 1930; Pascual in Pascual et al. 1966; Pérez et al. 2014).

The oldest record of 'cardiomyines' is an isolated lower molar from the Río Frías Formation (Guenguel River; Mayoan SALMA assigned to the middle Miocene dated as 11.5 Ma; Dal Molin \& Franchi 1996) that has been tentatively referred to Cardiomys? andinus (Kraglievich 1930; Vucetich \& Pérez 2011). However, 'cardiomyines' are well recorded from the early late Miocene to the Pliocene, as four genera with several species; Xenocardia Pascual \& Bondesio, 1963, Procardiomys Pascual, 1961, Cardiomys Ameghino, 1885 and Caviodon Ameghino, 1885 (Figs 1, 2).

A revision of the material from various collections of Argentina and the USA suggested that the diversity of these rodents during the late Miocene was higher than so far known. One skull from the Andalhuala Formation of Catamarca ('Araucanian'), notable for its preservation, was collected by the Second Marshall Field Paleontological Expedition to Argentina in 1926 together with some mandible remains, and is housed in the Field Museum of Natural History, Chicago, USA. This skull, FMNH P 14457, was catalogued as Cardiomys ameghinorum, a common species for the late Miocene of north-western Argentina (Marshall \& Patterson 1981): this determination is here revised. Another quite complete skull, housed in the Museo de La Plata (MLP 55-IV-28-11), was catalogued in schedis as Cardiomys sp. but was unpublished. It was found in the Arroyo Chasicó Formation (late Miocene) cropping out on the banks of Arroyo Chasicó, south-west Buenos Aires Province. In this paper both skulls and other materials housed in the FMNH and MLP, referred to 'cardiomyines' are studied and scored for inclusion in a phylogenetic analysis, to improve our understanding of the relationships of the group. In addition, a synonymy of species of Caviodon from the Conglomerado osífero of the Ituzaingó Formation (late Miocene; also known as Mesopotamian) is proposed. Evolutionary and biogeographical issues resulting from the new taxonomic arrangement are also addressed.

\section{MATERIAL AND METHOD}

Taxonomic nomenclature. According with the taxonomic and phylogenetic analyses conducted here, 'Cardiomyinae' is not the valid status of this group; therefore quotation marks are used for this assemblage of basal hydrochoerines.

Dental and anatomical nomenclature. Nomenclature and abbreviations for dental structures (Fig. 3) refer to the Spanish names in order to conform to previous publications (Frailey 1986), and follow Vucetich et al. (2011).

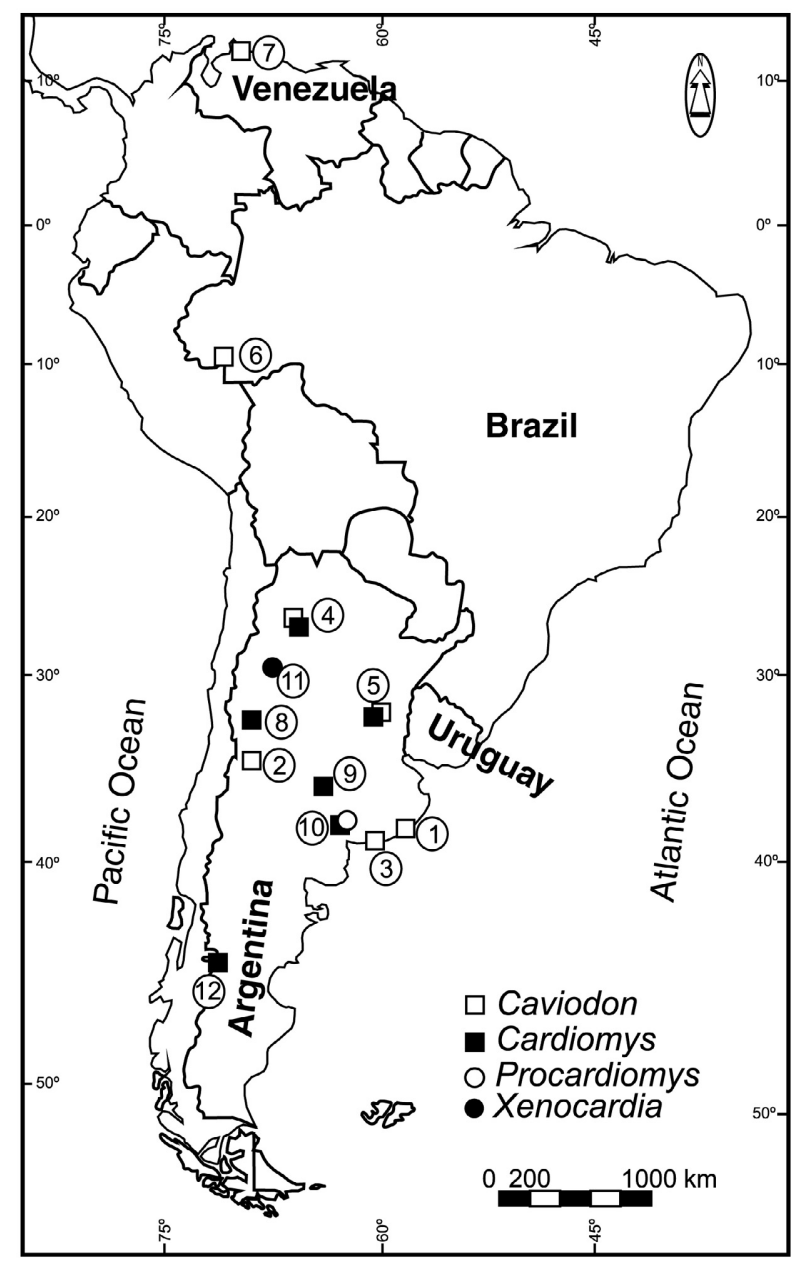

FIG. 1. Location map with the South American records of 'cardiomyines'. 1, Chapadmalal Formation, Chapadmalal, Buenos Aires Province; 2, Aisol Formation, Arroyo Seco de la Frazada, Mendoza Province; 3, Monte Hermoso Formation, Farola Monte Hermoso, Buenos Aires Province; 4, Andalhuala Formation, Río de Yapes, Catamarca Province; 5, Conglomerado osífero of the Ituzaingó Formation, Paraná River Banks, Entre Ríos Province; 6, Madre de Dios Formation, Western Amazonia, Peru; 7,San Gregorio Formation, San Gregorio, Venezuela; 8, Huayquerías Formation, Huayquerías de San Carlos, Mendoza Province; 9, Cerro Azul Formation, several localities, La Pampa Province; 10, Arroyo Chasicó Formation, Arroyo Chasicó, Buenos Aires Province; 11, Huachipampa Formation, Loma del Camello, San Juan Province; 12, Río Frías Formation, Chubut Province. For temporal calibration of units see Deschamps et al. (2013), Vucetich et al. (2011), Milana et al. (2003).

The mandibular nomenclature follows that of Woods \& Howland (1979) and Pérez (2010). The postcranial nomenclature follows that of Popesko et al. (2003) and Schaller (2007).

Upper and lower case letters refer to upper and lower teeth, respectively; i, p4, $\mathrm{m} 1-3$ and $\mathrm{I}, \mathrm{P} 4, \mathrm{M} 1-3$ refer to lower and upper incisor, fourth premolar, and molars 
FIG. 2. Stratigraphical and geographical distribution of 'cardiomyines'. 1, Chapadmalal Formation, Chapadmalal, Buenos Aires Province; 2, Aisol Formation, Arroyo Seco de la Frazada, Mendoza Province; 3, Monte Hermoso Formation, Farola Monte Hermoso, Buenos Aires Province; 4, Andalhuala Formation, Río de Yapes, Catamarca Province; 5, Conglomerado osífero of the Ituzaingó Formation, Paraná River Banks, Entre Ríos Province; 6, Madre de Dios Formation, Western Amazonia, Peru; 7, San Gregorio Formation, San Gregorio, Venezuela; 8, Huayquerías Formation, Huayquerías de San Carlos, Mendoza Province; 9, Cerro Azul Formation, several localities, La Pampa Province; 10, Arroyo Chasicó Formation, Arroyo Chasicó, Buenos Aires Province; 11, Huachipampa Formation, Loma del Camello, San Juan Province; 12, Río Frías Formation, Chubut Province. For temporal calibration of units see Deschamps et al. (2013), Vucetich et al. (2011), Milana et al. (2003).

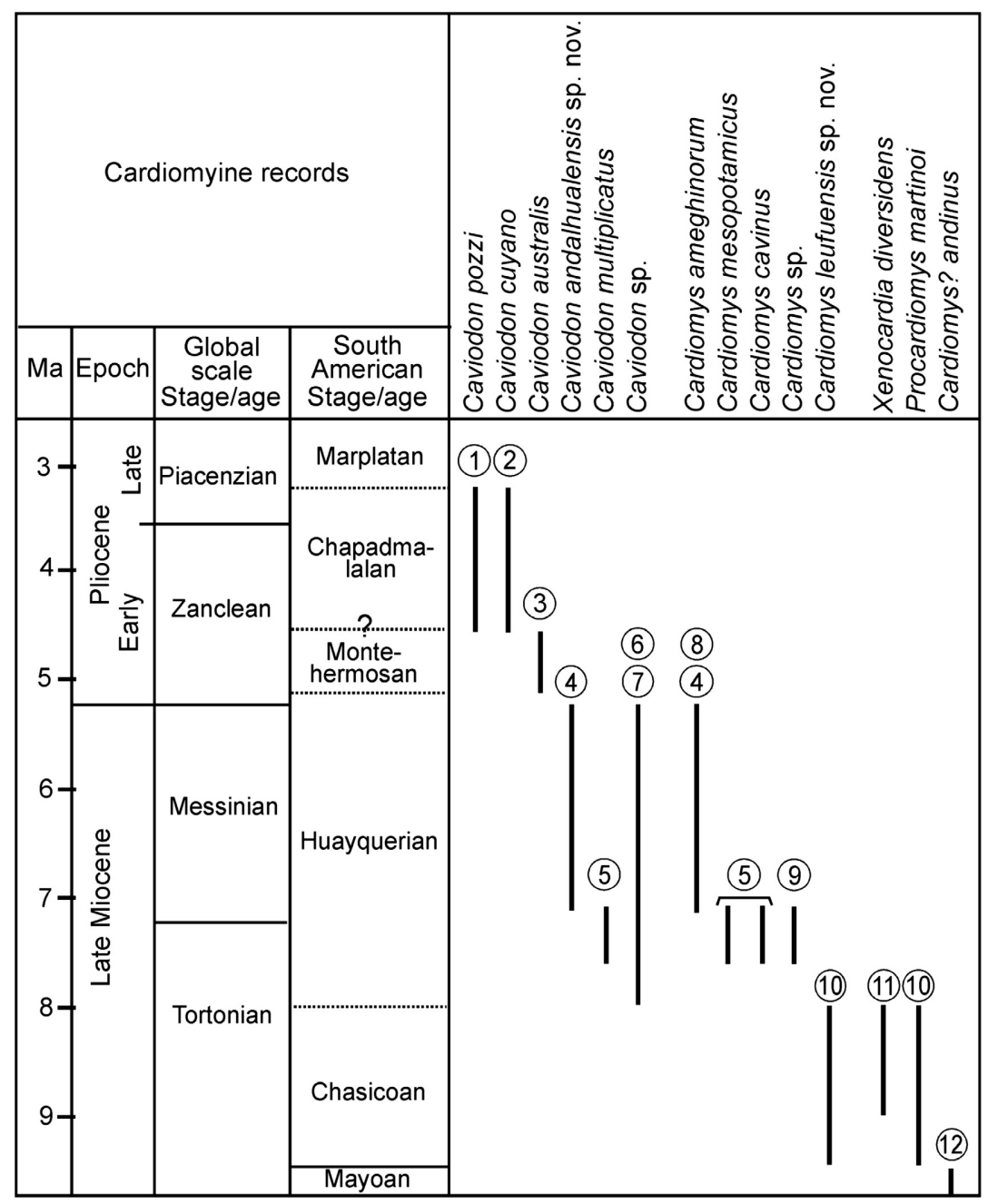

A

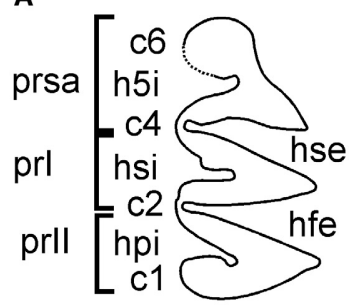

B

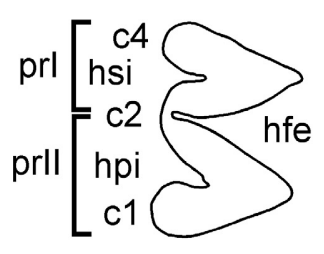

C

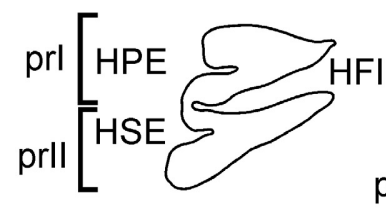

D

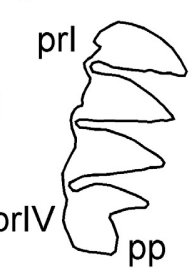

E

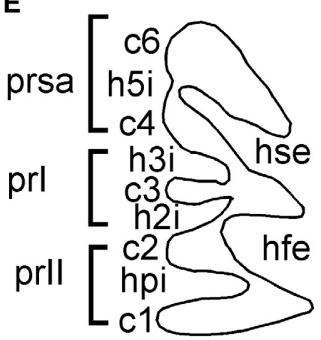

FIG. 3. Dental nomenclature of 'cardiomyines' and $\mathrm{p} 4$ of derived hydrochoerines. A, p4. B, m1 or m2. C, M1 or M2. D, M3. E, p4. Abbreviations: Upper and lower case letters refer to upper and lower teeth, respectively: i, p4, m1-3, and I, P4, M1-3 refer to lower and upper incisor, fourth premolar and molars 1-3; c1, c2, c3, c4, c6, columns 1, 2, 3, 4, 6; h2i/h3i/h5i, second/third/fifth internal fissure; hfe, fundamental external fissure (= hypoflexid); HFI, fundamental internal fissure (= hypoflexus); hpi/HPE, primary internal/external fissure; hse, secondary external fissure; hsi/HSE, secondary internal/external fissure; pp, posterior projection; prI-IV, prisms IIV; prsa, supernumerary anterior prism.

1-3; c1, c2, c3, c4, c6 columns 1, 2, 3, 4, 6; hpi/HPE, primary internal/external fissure; hse, secondary external fissure; hsi/HSE, secondary internal/external fissure; h5i, fifth internal fissure; HFI, fundamental internal fissure
(= hypoflexus); hfe, fundamental external fissure (= hypoflexid); nMpi, notch for the insertion of the tendon of the masseter medialis pars infraorbitalis muscle; prI-II, prisms I-II; prsa, supernumerary anterior prism. 
The hsi in the simple lower premolars (i.e. three prisms with only hpi, hsi, and h5i) of Hydrochoerinae such as Kerodon, Cardiomys and Caviodon is here interpreted as homologous to h3i (or hsia sensu Mones 1991) of complex lower premolars (i.e. three prisms with more lingual fissures than hpi, hsi and h5i) of most derived Hydrochoerinae such as Cardiatherium, Phugatherium, Hydrochoeropsis, Neochoerus and Hydrochoerus (Fig. 3E). This interpretation is based on that h3i (as hsi) is in prI in all species of Hydrochoerinae, whereas h2i is in prI or prII; moreover, h2i is usually shallower than $\mathrm{h} 3 \mathrm{i}$.

Dental measurements. AP, anteroposterior length; AW, anterior width measured at the first prism; HPEL, HPE length; HPIL, hpi length; HSEL, HSE/hse length; HSIL, hsi length; HFEL, hfe length; MW, middle width, prI width of p4; PW, posterior width measured at the last prism (Table 1).

Morphological analysis. The comparative morphological study of the material was made using the holotypes of 'cardiomyine' species; some of them are the single specimens of the taxon, even isolated teeth, and others from Argentine museums referred to 'cardiomyines' (Appendix).

Phylogenetic analysis. To test the phylogenetic position of the new species and the relationships of the 'cardiomyines' within Caviidae, a phylogenetic analysis was performed based on the data matrix of Pérez et al. (2017a). The combined matrix (Pérez et al. 2017b, suppl. data 1) for this analysis comprises 59 taxa (root: Proechimys; basal cavioids: Cuniculus, Dasyprocta, Neoreomys, 'eocardiids'; and Caviidae: Caviinae, Dolichotinae and Hydrochoerinae), 133 morphological characters (mandibular, cranial, dental and postcranial) and 4014 characters from DNA sequences of nuclear and mitochondrial genes (Pérez et al. 2017b, suppl. data 2). The equally weighted parsimony analysis was conducted using TNT 1.1 (Goloboff et al. 2008a, b), performing a heuristic search of 1000 Wagner tree replicates followed by TBR branch swapping, collapsing zero-length branches under the strictest criterion. Unstable taxa in the set of the most parsimonious trees (MPTs) were identified using IterPCR (Pol \& Escapa 2009) to derive an informative reduced consensus. Support values were calculated using Bremer indices and Bootstrap. Bremer support was calculated using the script BREMER.RUN provided with TNT, and resampling techniques were conducted with 1000 pseudoreplicates in TNT. Support analyses were conducted on the complete dataset, but the fossil taxon Allocavia (which was unstable in the MPTs) was pruned from the resulting trees to detect support values irrespective of the alternative positions of this fragmentary taxon in the suboptimal trees (for Bremer support) and in the trees derived from the resampling techniques.

Institutional abbreviations. FMNH P, Paleontological Collection, Field Museum of Natural History, Chicago, USA; MACN A, Museo Argentino de Ciencias Naturales, Ameghino Collection, Buenos Aires, Argentina; MACN-Pv, Museo Argentino de Ciencias Naturales, Vertebrate Paleontology Collection, Buenos Aires, Argentina; MHNSR-PV, Museo de Historia Natural de San Rafael, Mendoza, Argentina; MLP, Museo de La Plata, La Plata, Argentina; MMH-CH, Museo Municipal de Monte Hermoso 'Vicente Di Martino', Colección Chasicó, Argentina; MMP, Museo Municipal de Mar del Plata, Mar del Plata, Argentina; UFAC, Universidade Federal do Acre (Campus Rio Branco).

\section{SYSTEMATIC PALAEONTOLOGY}

\author{
Order RODENTIA Bowdich, 1821 \\ Suborder HYSTRICOGNATHI Tullberg, 1899 \\ Superfamily CAVIOIDEA (Fischer de Waldheim, 1817) \\ Family CAVIIDAE Fischer De Waldheim 1817 \\ Subfamily HYDROCHOERINAE Gray, 1825
}

Genus CAVIODON Ameghino, 1885

1888 Diacartherium Ameghino, pp. 10-11.

Type species. Caviodon multiplicatus Ameghino, 1885.

Diagnosis. Large caviomorphs with euhypsodont check teeth and bilobular P4-M2 and m1-m3 (modified from Pascual in Pascual et al. 1966). M3 formed by five to seven prisms, the last of which may have a posterior extension variably developed; $\mathrm{p} 4$ formed by three prisms; hpi and hsi of p4 present and similar in depth; m1-m3 and P4-M2 with his-hpi and HPE-HSE subequal in depth and proportionally deeper than in Cardiomys and Procardiomys, and located close to the middle of the prism; prisms transversely longer and with straighter margins than in Cardiomys and Procardiomys; prisms of M3 lanceolate except the first or two first prisms, which are heart-shaped; M1 anteroposteriorly shorter than P4 and M2; palate broad and almost flat, similar to the condition of Cardiatherium, and the most derived hydrochoerines (Phugatherium, Hydrochoeropsis, Neochoerus and Hydrocherus; Fig. 3E); mesopterygoid fossa wide and rounded in ventral view; dorsal border of the skull at the level of the frontal-parietal bones, mainly flat; sagittal crest present; shallow temporal fossae.

Included species. The type species, C. australis (Ameghino, 1888), C. pozzi Kraglievich, 1927, C. cuyano Vucetich et al., 2011 and C. andalhualensis sp. nov. 
TABLE 1. Dental measurements (in $\mathrm{mm}$ ).

\begin{tabular}{|c|c|c|c|c|c|c|}
\hline Species & Tooth & $\mathrm{AP}$ & prIW & prIIW & prsaW & npr \\
\hline \multicolumn{7}{|c|}{ Caviodon andalhualensis sp. nov. } \\
\hline FMNH P 15287 & $\mathrm{p} 4$ & 9.12 & 4.41 & 4.26 & 4.36 & \\
\hline \multirow[t]{3}{*}{ FMNH P 14434} & $\mathrm{p} 4$ & 9.81 & 4.78 & 4.85 & & \\
\hline & $\mathrm{m} 1$ & 7.59 & & 4.36 & & \\
\hline & $\mathrm{m} 2$ & & 5.01 & & & \\
\hline FMNH P 14457 & $\mathrm{P} 4$ & & & & & \\
\hline \multirow[t]{3}{*}{ Holotype } & M1 & 6.44 & 5.69 & 5.13 & & \\
\hline & M2 & 7.11 & 5.51 & 6.34 & & \\
\hline & M3 & 16.6 & 5.85 & & & 6 \\
\hline \multicolumn{7}{|c|}{ Caviodon multiplicatus } \\
\hline $\begin{array}{l}\text { MACN-Pv } 5891 \\
\text { Holotype }\end{array}$ & M3 & 10.8 & 4.9 & & & 5 \\
\hline \multicolumn{7}{|l|}{ Caviodon cuyano } \\
\hline MHNSR-PV 1101 & $\mathrm{p} 4$ & 14.24 & 6.56 & 7.04 & 6.08 & \\
\hline \multirow[t]{7}{*}{ Holotype } & $\mathrm{m} 1$ & 9.76 & 7.04 & 7.2 & & \\
\hline & $\mathrm{m} 2$ & 9.6 & 7.68 & 8.08 & & \\
\hline & $\mathrm{m} 3$ & 12 & 7.84 & 8.04 & & \\
\hline & $\mathrm{P} 4$ & 8.96 & 5.76 & 7.2 & & \\
\hline & M1 & 7.36 & 6.72 & 7.36 & & \\
\hline & M2 & 8 & 6.72 & 8.16 & & \\
\hline & M3 & 19.56 & 7.74 & & & 7 \\
\hline \multicolumn{7}{|l|}{ Caviodon australis } \\
\hline \multirow[t]{2}{*}{ MACN-Pv 14481} & $\mathrm{~m} 1$ & 7.5 & 4.95 & 5.4 & & \\
\hline & $\mathrm{m} 2$ & 7.5 & 5.55 & 5.55 & & \\
\hline MACN A-1099 & $\mathrm{P} 4$ & 9.41 & 5.88 & 7.01 & & \\
\hline \multirow[t]{3}{*}{ Holotype } & M1 & 7.55 & 6.25 & 6.81 & & \\
\hline & M2 & 8.21 & 6.31 & 7.01 & & \\
\hline & M3 & 19.3 & 6.26 & & & 6 \\
\hline \multicolumn{7}{|l|}{ Caviodon pozzi } \\
\hline MACN-Pv 6915 & $\mathrm{p} 4$ & 10.35 & 5.1 & 5.25 & 4.8 & \\
\hline \multirow[t]{2}{*}{ Holotype } & $\mathrm{m} 1$ & 7.25 & 5.25 & 5.1 & & \\
\hline & $\mathrm{m} 2$ & 7.8 & 6 & 6 & & \\
\hline \multirow[t]{4}{*}{ MMP 525-M } & $\mathrm{P} 4$ & 7.36 & 5.12 & 6.24 & & \\
\hline & M1 & 5.92 & 5.44 & 6.08 & & \\
\hline & M2 & 6.4 & 5.44 & 5.76 & & \\
\hline & M3 & 14.45 & 5.42 & & & 6 \\
\hline \multicolumn{7}{|c|}{ Cardiomys leufuensis sp. nov. } \\
\hline \multirow[t]{3}{*}{ MLP 76-VI-12-92 } & $\mathrm{p} 4$ & 11.2 & 5 & 5.51 & 4.9 & \\
\hline & $\mathrm{m} 1$ & 7.8 & 6 & 5.7 & & \\
\hline & $\mathrm{m} 2$ & 8.6 & 5.6 & 6.8 & & \\
\hline MLP 55-IV-28-11 & $\mathrm{P} 4$ & 7.25 & & 5.54 & & \\
\hline \multirow[t]{3}{*}{ Holotype } & M1 & 5.19 & 4.8 & 4.93 & & \\
\hline & M2 & 6.8 & 5.2 & 5.7 & & \\
\hline & M3 & 11.9 & 4.95 & & & 4 \\
\hline \multicolumn{7}{|l|}{ Cardiomys cavinus } \\
\hline MACN-Pv 4593 & $\mathrm{~m} 1$ & 6.59 & 4.78 & 4.95 & & \\
\hline Metatype (1) & $\mathrm{m} 2$ & 6.47 & 5.16 & 5.02 & & \\
\hline sensu & $\mathrm{m} 3$ & 8.63 & 5.61 & 5.44 & & \\
\hline \multicolumn{7}{|l|}{ Kraglievich 1932} \\
\hline \multicolumn{7}{|c|}{ Cardiomys ameghinorum } \\
\hline MACN-Pv 8247 & $\mathrm{p} 4$ & 10.6 & 5.23 & 5.84 & & \\
\hline \multirow[t]{3}{*}{ Holotype } & $\mathrm{m} 1$ & 7.81 & 5.92 & 5.92 & & \\
\hline & $\mathrm{m} 2$ & 7.44 & 5.89 & 5.91 & & \\
\hline & $\mathrm{m} 3$ & 8.68 & 6.16 & 6.55 & & \\
\hline
\end{tabular}

TABLE 1. (Continued)

\begin{tabular}{lllllll}
\hline Species & Tooth & AP & prIW & prIIW & prsaW & npr \\
\hline MACN-Pv 8246 & P4 & 7.4 & & 5.54 & & \\
& M1 & 5.19 & 4.8 & 4.93 & & \\
& M2 & 5.8 & 4.72 & 5.21 & \\
& M3 & 12.9 & 4.54 & & 4 \\
\hline
\end{tabular}

$\mathrm{AP}$, anteroposterior length; npr, number of prisms; prI/IIW, width of prism I/II; prsaW, width of supernumerary anterior prism.

Geographical and stratigraphical distribution. Late Miocene (Huayquerian; Conglomerado osífero of the Ituzaingó Formation, Paraná, Entre Ríos); early Pliocene (Montehermosan; Monte Hermoso Formation, Farola Monte Hermoso, Buenos Aires); late Pliocene (Chapadmalalan; Chapadmalal Formation, Buenos Aires; Aisol Formation, Arroyo Seco de la Frazada, Mendoza; late Miocene (Huayquerian) of Solimoes Formation, Patos, Brazil; and Pliocene of the San Gregorio Formation, San Gregorio, Venezuela (Fig. 1).

\section{Caviodon multiplicatus Ameghino, 1885}

1927 Caviodon bravardi Kraglievich, p. 593.

1930 Caviodon (Lelongia) paranensis Kraglievich, pp. 181-184, fig. 1.

1932 Caviodon (Paracaviodon) angustidens Kraglievich, p. 179.

1932 Caviodon scalai Kraglievich, p. 176.

Holotype. MACN-Pv 5891: right M3.

Remarks. These species of Caviodon were based on isolated M3 from the same geographical and stratigraphical provenance (see Appendix). They differ only in increasing size and depth of labial fissures, as well as in the addition of posterior prisms with size/age (Table 1). In this regard, Vucetich et al. (2011) had already suggested that Caviodon bravardi and C. (Lelongia) paranensis are synonymous; they interpreted their differences as ontogenetic variation (Vucetich et al. 2005). The holotypes of C. (Paracaviodon) angustidens and C. scalai are lost; however, the description and measurements given by Kraglievich (1932) are within the range of ontogenetic variation of C. multiplicatus. In this context, we propose that these species are synonyms of C. multiplicatus.

\section{Caviodon andalhualensis sp. nov. Figures 4-7}

LSID. urn:lsid:zoobank.org:act:A7FDEB09-4E38-4A71-972548440243C3DA 
Derivation of name. In reference to the bearing unit, the Andalhuala Formation.

Holotype. FMNH P 14457: skull, atlas, axis and three cervical vertebrae.

Type locality. Locality 4, Río de Yapes, level XX (Marshall \& Patterson 1981).

Diagnosis. Caviodon andalhualensis sp. nov. differs from other species of Caviodon by a unique set of characters: skull more robust than C. pozzi but less robust than C. cuyano; cheek teeth with relatively thin prisms with HPE and HSE shallower than in C. pozzi and C. cuyano, deeper than in C. multiplicatus, and more transversal than in C. australis; M3 with six prisms plus a thin and long posterior projection (Fig. 5A) transversally oriented as in C. pozzi (Fig. 5E), but different from the condition of C. cuyano which has seven prisms (Fig. 5D), C. australis which has five prisms plus a rounded posterior projection, and C. multiplicatus which has five prisms plus a thin posterior projection (Fig. $5 \mathrm{~F}-\mathrm{H}$ ); mesopterygoid fossa relatively narrower than in C. cuyano and C. pozzi.

Horizon and locality. Valle de Santa María, Locality 4, Río de Yapes, level XX; Puerta de Corral Quemado, above level 19 (Marshall \& Patterson 1981). Levels XX and 19 belong to the Andalhuala Formation and are below level 23 , which is dated as $5.30 \pm 0.2 \mathrm{Ma}$ and $5.64 \pm 0.16$ (Butler et al. 1984 and Latorre et al. 1997, respectively), and above level 15, dated as $6.70 \pm 0.05 \mathrm{Ma}$ and $7.14 \pm 0.02 \mathrm{Ma}$ (Butler et al. 1984 and Latorre et al. 1997, respectively) (see Esteban et al. 2014). Therefore, a late Miocene Messinian age is proposed for the fossilbearing sediments.

Referred material. FMNH P 14434, right jaw fragment with p4-m2, from level 15-32 (in schedis 'above level 19') and FMNH P 15287, left jaw fragment with p4 (no horizon), were assigned to Cardiomys ameghinorum latidens in schedis and by Marshall \& Patterson (1981). However, because of their deep hsi and hpi in the middle of the prisms, including in the middle prism (prI) of $\mathrm{p} 4$, similar to those of upper teeth of $C$. andalhualensis sp. nov., they are here transferred to this taxon.

\section{Description}

Skull. The premaxilla occupies the anterior portion of the rostrum and has a conspicuous anterior ridge, dorsal to the incisor alveolus and anteroventral to the nasal cavity; it is more vertical than that of C. pozzi, which is oblique. It cannot be compared with other species of Caviodon because the specimens are broken. The skull of C. andalhualensis is narrower than that of C. cuyano (Fig. 6A-C).

In dorsal view (Fig. 4A), the nasals are flat (these bones are missing in C. pozzi, and are broken in C. cuyano). The anterior end of the nasals is posterior to the anteriormost part of the premaxilla. The frontals are also flat, like those of C. pozzi. The parietals are slightly convex posteriorly and have a medial sagittal crest. Laterally there is a shallow temporal fossa.

In lateral view (Fig. 4B), the ascendant ramus of the premaxilla is wider at the posterior margin, and more backwardly extended (surpassing the naso-frontal suture) than in C. pozzi (in which it extends up to this suture). The masseteric fossa is anteriorly formed by the premaxilla and posteriorly by the maxilla; the fossa is deeper and its dorsal, anterior and ventral margins are more developed than in C. pozzi (this feature cannot be seen in C. cuyano). In both species (C. andalhualensis and C. pozzi) the diastema is shorter than the cheek teeth series (Table 1), but in C. pozzii the diastema has a different height and inclination, as the incisor alveolus is above the line of the cheek teeth series. The orbit appears to be displaced backwards relative to the tooth row as in C. pozzi. Above the dorsal root of the antorbital bar there is a horizontal canal (Fig. 4B), which is very conspicuous as a double wave in Cardiatherium and Phugatherium, but is shorter in other caviomorphs.

In ventral view (Fig. 4C), the palate of C. andalhualensis is narrower than in C. australis and C. cuyano. The maxilla-palatine suture does not contact the palatine foramina, unlike C. pozzi in which it does. The maxillary area of the palate occupies $50 \%$ of the palate, as in C. pozzi and C. australis, unlike C. cuyano in which this area is short and narrow, although in the three species the suture is at the level of the posterior lobe of M2. The posterior margin of the anterior root of the zygomatic arch is, as in C. cuyano, slightly posterior than in C. pozzi. The mesopterygoid fossa is narrower than in C. pozzi and C. cuyano. The pterygoids (right and left) of the new species are closer to each other than those of C. pozzi. The posterolateral extensions of the palatine are wider than in C. pozzi and C. cuyano. The mesopterygoid fossa occupies $50.84 \%$ the width of the palatine at the level of the last prism of M3 $(60 \%$ in C. cuyano and $61 \%$ in C. pozzi).

The basicranium is rather complete with the sphenoid complex (orbitosphenoid, presphenoid, basisphenoid, alisphenoid), the basioccipital and the ectotympanic (Fig. 4C). The presphenoid is long and narrow; it is anteriorly fused to the orbitosphenoid, laterally to the alisphenoid and posteriorly to the basisphenoid. This latter is anteriorly thin, posteriorly wide and fused to the basioccipital. The alisphenoid is a thin lamina slightly sloping and laterally joined to the glenoid cavity of the squamosal. The basioccipital is robust, wide and laterally in contact with the ectotympanic, which is globose but relatively small in comparison with the skull (similar to other hydrochoerines). The occipital condyle is dorsoventrally elongated (Fig. 4C). The occipital is slightly posteriorly concave and has a dorsal ridge through its entire border. 


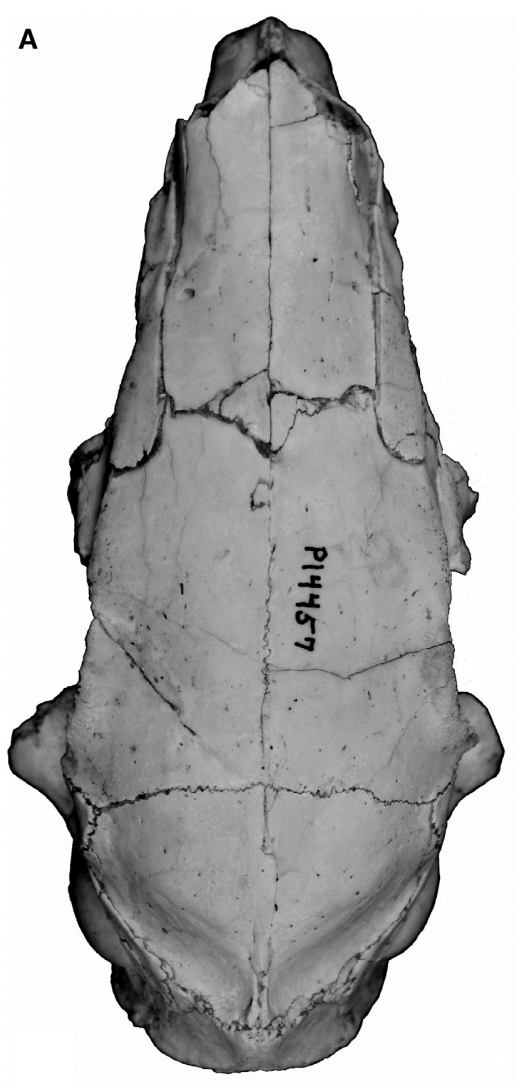

D

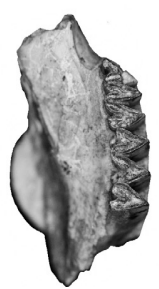

$\mathbf{E}$

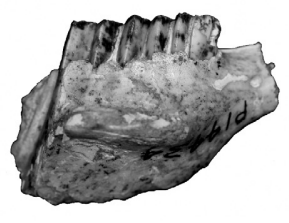

B

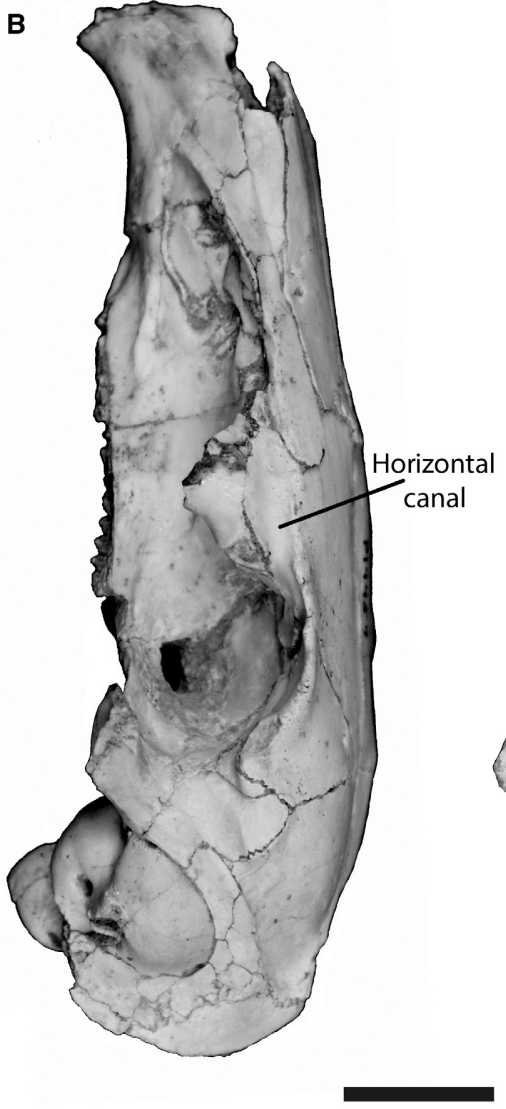

$\mathbf{F}$

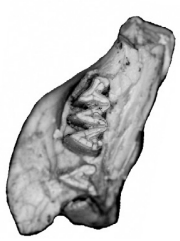

G

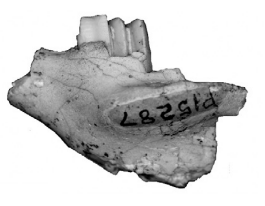

H

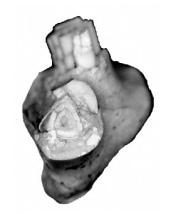

FIG. 4. Caviodon andalhualensis sp. nov. A-C, FMNH P 14457, skull: A, dorsal; B, lateral; C, ventral view. D-E, FMNH P 14372, right mandible fragment: D, occlusal; E, labial view. F-H, FMNH P 15287, left mandible fragment: F, occlusal; G, labial; H, frontal view with fragment of incisor. Scale bar represents $20 \mathrm{~mm}$.

Mandible. The preserved fragments of the dentary in FMNH P 14434 and FMNH P 15287 (Fig. 4D-H) are robust. The nMpi is placed between $\mathrm{p} 4$ and $\mathrm{m} 1$ below the alveolar line; it is large and forms a continuous and thick border that extends from the anterior margin of the $\mathrm{p} 4$ ascending posteriorly (Fig. 4E, G). The mental foramen is located anteriorly to $\mathrm{p} 4$ and at little above the level of nMpi.

Dentition. The incisor is preserved only in the intraalveolar portion; it is triangular in cross-section, being the proximal angle very acute (Fig. $4 \mathrm{H}$ ). P4-M2 and $\mathrm{m} 1-\mathrm{m} 3$ are double-hearted; M3 has six prisms and a small posterior projection; $\mathrm{p} 4$ has three prisms. Some features participate in the shape of molariforms, mainly the anteroposterior length of each prism, the location of the fissure, its depth and its shape, as well as the shape of the hypoflex. All of the molariforms of the new species are narrower than those of C. cuyano and Cardiomys, and thicker than C. pozzi and C. australis.

Upper teeth. HPE and HSE of P4-M2 of C. andalhualensis (Fig. 5A) penetrate less than $30 \%$ of the occlusal surface of the prism as in C. australis (Fig. 5B, C), in contrast with the condition of C. cuyano and C. pozzi (Fig. 5D, E) in which these fissures penetrate up to almost $50 \%$ of the width of the occlusal surface. The M3 of C. andalhualensis has six prisms and a small posterior projection, as in C. pozzi (Fig. 5A, E). C. australis has six prisms (the last one thicker, Fig. 6D) and C. cuyano has seven prisms on the right dental series, while on the left it has seven prisms plus a small posterior projection (Fig. 6B). The fissures of the new species are deeper, especially those of prisms 1-4, than those of C. multiplicatus and C. australis, but shallower than in C. pozzi and C. cuyano. 


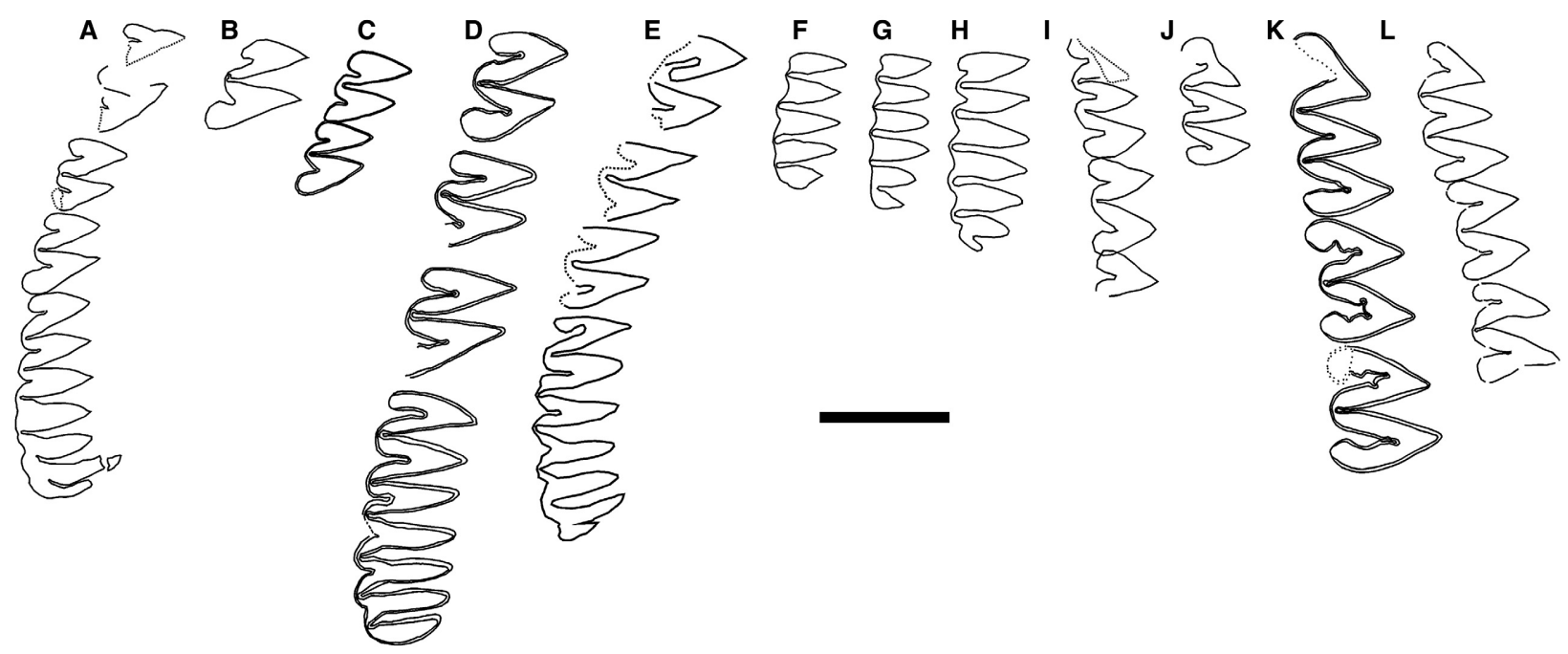

FIG. 5. Occlusal schemes of the dental series of the species of Caviodon. A-H, upper teeth; I-L, lower teeth. A, I-J, Caviodon andalhualensis sp. nov. B-C, Caviodon australis. D, K, Caviodon cuyano. E, L, Caviodon pozzi. F-H, Caviodon multiplicatus. A, FMNH P 14457 (holotype), right P4-M3. B, MACN A-1099 (holotype of Diacartherium australe) left P4 (reversed). C, MACN-Pv 7326, left M1-M2 (reversed). D, MHNSR-PV 1101 (holotype) right P4-M3. E, MMP 525-M, right P4-M3. F, MACN-Pv 5891 (holotype) right M3. G, MACN-Pv 4495 (holotype of Caviodon bravardi, left M3. H, MACN-Pv 13471 (holotype of Caviodon (Lelongia) paranense), right M3. I, FMNH P 14434, right p4-m1 and prI of m2. J, FMNH P 15287 right p4. K, MHNSR-PV 1101 right p4-m2. L, MACN-Pv 6915 (holotype) right p4-m2. Scale bar represents $10 \mathrm{~mm}$.

Lower teeth. The lower molariforms of C. andalhualensis are wider than in C. pozzi and C. australis and narrower than in C. cuyano (Fig. 5).

The prsa of $\mathrm{p} 4$ is lingually long due to an anterolingual widening (Fig. 5I, J). The prI is the narrowest and has a single deep fissure, unlike Cardiomys in which this prism lacks hsi or has two very shallow ones. The hse and hfe are very deep and have cement. The h5i, hsi and hpi are deep, with different curvature and orientation. The enamel is interrupted in $\mathrm{cl}$ and $\mathrm{c} 4$ (Fig. 4).

The $\mathrm{m} 1-\mathrm{m} 2$ are bilobed and double heart-shaped with funnel-shaped hfe, and the hsi and hpi relatively deep (Fig. 5I, J).

Postcranium. Among the cardiomines, only a few postcranial elements of Caviodon cuyano have been described (Vucetich et al. 2011). However, the preserved bones (sacrum, femora, knee joint, some phalanges and sesamoids) are different from those preserved in C. andalhualensis, and thus cannot be compared. Only the atlas, axis and the following three cervical vertebrae (3-5) are known for C. andalhualensis. The atlas (Fig. 7A) is mostly complete, showing the spinous process dorsally, the transverse process, the cranial articular fovea, transverse foramen, and foramen of wing. The cranial articular fovea is covered with sediment. The axis (Fig. 7B, C) presents in anterior (or cranial) view the conspicuous spinous process and the vertebral arch, whereas the transverse process is broken. The caudal articular process and caudal extremity of corpus (vertebral fossa), both relatively large, are seen in posterior (or caudal) view; the little ventral tubercle is seen in ventral view. The other three cervical vertebrae 3-5 (Fig. 7D) are smaller, still articulated, and with part of the spinous process; the cranial extremity of body and the ventral plate are seen in anterior view. The vertebral arch, caudal articular process, caudal extremity of corpus and the ventral plate are preserved.

Genus CARDIOMYS Ameghino, 1885

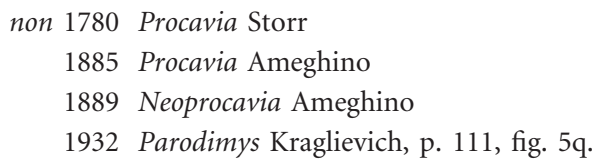

Type species. Cardiomys cavinus Ameghino, 1885.

Diagnosis. Medium size caviomorphs with euhypsodont check teeth and bilobular P4-M2 and m1-m3 (modified from Pascual in Pascual et al. 1966). M3 composed of four main prisms and a posterior extension, more or less developed; all prisms relatively compressed anteroposteriorly, with an external fissure in each one, or with two very shallow fissures in the third and fourth prisms; p4 composed by three prisms, prsa with very shallow h5i or not present, prI with hsi absent forming a convex lingual margin, or with two very shallow fissures next to columns c2 and c4, the margin being straight, depressed with respect to the lingual margin, prII with deeper hpi next to c2; the remaining molars with hsi and hpi/HPE and HSE shallower, different in depth, and closer to c2 than in Caviodon; temporal fossae relatively deep. It differs from Procardiomys which has only three prisms in 


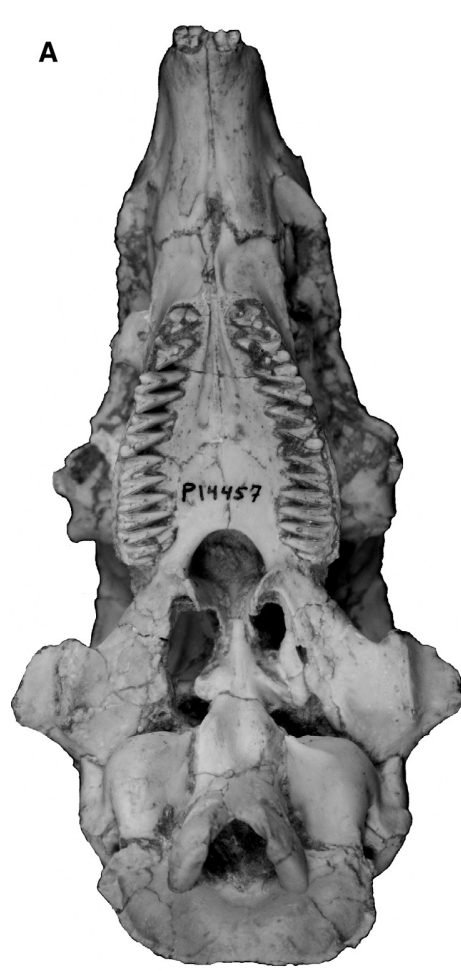

B
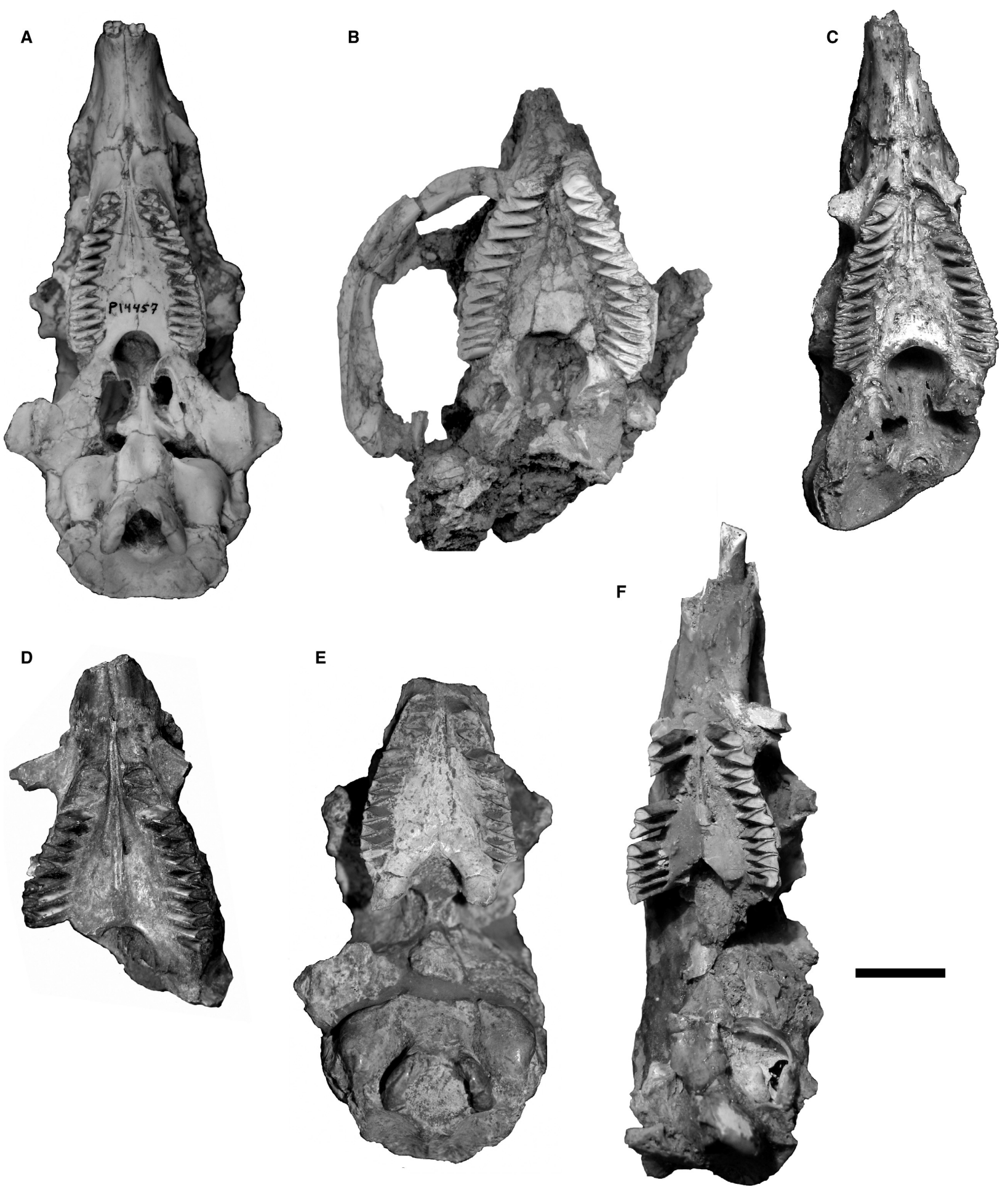

FIG. 6. Comparison of 'cardiomyine' skulls in ventral view. A, FMNH P 14457, Caviodon andalhualensis sp. nov. B, MHNSR-PV 1101, Caviodon cuyano. C, MMP 525-M, Caviodon pozzi. D, MACN-Pv 7326, Caviodon australis. E, MACN-Pv 8246, Cardiomys ameghinorum. F, MLP 55-IV-28-11, Cardiomys leufuensis sp. nov. Scale bar represents $20 \mathrm{~mm}$.

the M3 and the external fissures are shallower; from Kerodon because it has two prisms in M3, and from Xenocardia, Caviodon, Cardiatherium, Phugatherium,
Hydrochoeropsis, Neochoerus and Hydrochoerus because these all have five or more prisms in M3 with deeper labial flexi. 
Included species. Cardiomys ameghinorum Rovereto, 1914 (including C. ameghinorum var. latidens Rusconi, 1914); Cardiomys mesopotamicus (Ameghino, 1885); Cardiomys? andinus Kraglievich, 1930; Cardiomys (Pseudocardiomys) intermedius Kraglievich, 1932; Cardiomys (Pseudocardiomys) minutus Kraglievich, 1932; Cardiomys (Pseudocardiomys) paranensis Kraglievich, 1932; Cardiomys (Pseudocardiomys) puelchensis Rusconi, 1944.

Remarks. Cardiomys vignatii Kraglievich, 1932 based on the specimen MACN-Pv 3944 probably belongs to Caviodon (see Discussion, below).

Geographical and stratigraphical distribution. Middle Miocene (Mayoan; Río Frías Formation, Chubut Province; 11.5 Ma; Dal Molin \& Franchi 1996); early late Miocene (Chasicoan; Arroyo Chasicó Formation, Buenos Aires); late Miocene (Huayquerian; Conglomerado osífero of the Ituzaingó Formation, Paraná, Entre Ríos; Cerro Azul Formation, La Pampa; Huayquerías Formation, Mendoza; Chiquimil, Andalhuala and Corral Quemado formations, Puerta de Corral Quemado, Valle de Santa María, Catamarca). The reports of Cardiomys from the Montehermosan and Chapadmalalan (Pascual et al. 1966; Tonni et al. 1992a, b) have not been corroborated. Probably the mention for the Montehermosan refers to lists including materials from the 'Mesopotamian' assemblage of the Conglomerado osífero, that was considered to range from the Chasicoan to the Montehermosan before the paper by Cione et al. (2000), and subsequent revisions of rodents (Vucetich \& Verzi, 1995; Vucetich et al. 2011, 2015, 2016). Even, in their revision of the mammals from Farola Monte Hermoso, Tomassini et al. (2013) reported Cardiomys sp. with doubts, from data taken from the literature. Its presence in Chapadmalal mentioned by Pascual et al. (1966) is probably a mistake because no material of this genus from this locality could be found.

\section{Cardiomys leufuensis sp. nov.}

Figures $6 \mathrm{~F}, 8,9 \mathrm{~A}, \mathrm{C}-\mathrm{F}$

LSID. urn:lsid:zoobank.org:act:129B5D17-E0D1-421B-A5AC6F5C6D366005

Derivation of name. From leufu, the Pampa word for Arroyo (Creek) in reference to the provenance, Arroyo Chasicó.

Holotype. MLP 55-IV-28-11: partial skull with right $\mathrm{P} 4$, M2-M3 and left P4-M3 (Fig. 8A-C).
Type locality. Campo Quinteros, margin of the Arroyo Chasicó, Buenos Aires Province; Arroyo Chasicó Formation, Late Miocene.

Diagnosis. The hpi and hsi of $\mathrm{m} 1-\mathrm{m} 2$ shallower than in C. cavinus (Fig. 9K); $\mathrm{m} 1-\mathrm{m} 2$ with narrower prisms than the molar of Cardiomys? andinus which is more heart-shaped or convex; skull more slender and palate narrower than in C. ameghinorum; prI of p4 has no hsi and the lingual wall is slightly convex, differing from C. ameghinorum in which the prI presents two small and very shallow fissures next to columns c2 and c4. It differs from C. mesopotamicus (Fig. 9I) in that the prI of C. leufuensisis more lingually extended, the prII is wider, the apex of hfe is directed forward, and hsi shallower. Cardiomys (Pseudocardiomys) paranensis has two small fissures in prI of the M2 in contrast with C. leufuensis that has only the HPE. Cardiomys intermedius, C. minutus and C. puelchensis are lost, but according to the descriptions, they would be different from C. leufuensis sp. nov. because: C. intermedius, coincides with the description of C. mesopotamicus especially in the morphology of $\mathrm{p} 4$; $\mathrm{p} 4$ of $C$. minutus presents the two small fissures in prI, differing from C. leufuensis which has only HPE; and p4 of C. puelchensis is smaller, and has two external fissures in prII (Rusconi 1944).

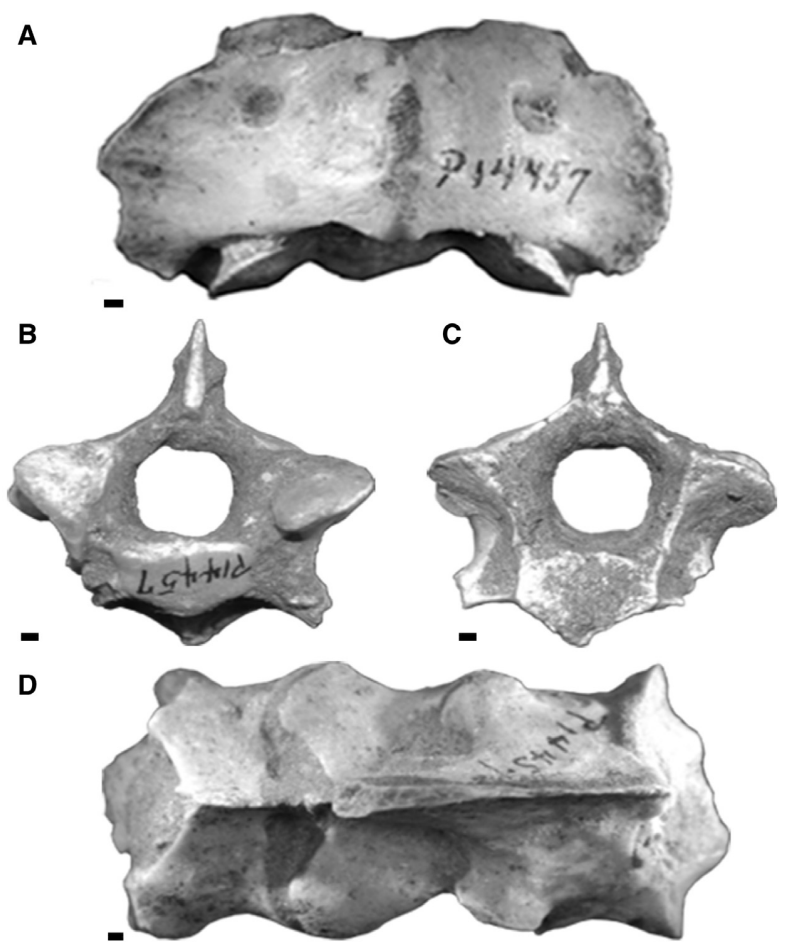

FIG. 7. Caviodon andalhualensis sp. nov. A, atlas. B-C, axis. D, cervicals (3-5). All scale bars represent $1 \mathrm{~mm}$. 
Horizon and locality. Arroyo Chasicó, Arroyo Chasicó Formation, Vivero and Las Barrancas members, Quebrada del Hacha, Bajada de los Toros.

Referred material. MLP 76-VI-12-18a, fragment of palate with right P4-M1 and left P4 (Fig. 8F); MLP 76-VI-12$18 \mathrm{~b}$, right mandible fragment with $\mathrm{p} 4-\mathrm{m} 3$ and left mandible fragment with p4-m1 (Fig. 8G); MLP 76-VI-12-92, left mandible fragment with p4-m2 (Fig. 8D); MLP 92XI-19-4, left mandible fragment with p4-m1; MLP 92-XI19-19, palate fragment with right $\mathrm{P} 4-\mathrm{M} 3$ and left $\mathrm{P} 4-\mathrm{M} 2$, and both anterior rami of the zygomatic arch (Fig. 8E). The specimens MLP 76-VI-12-18a, b with palate and mandible fragments allow assignment of the mandibles MLP 92-XI-19-4 and MLP 76-VI-12-92 to this species. MLP 92-XI-19-4 has previously been referred to Procardiomys martinoi (Vucetich \& Pérez 2011), but later Pérez et al. (2014) considered it tentatively as Cardiomys.

\section{Description}

Skull. Specimen MLP 55-IV-28-11 consists of a partially preserved skull, without the anterior portion of the rostrum; its left side is the best preserved (Fig. 8A-C). It can only be compared with Cardiomys ameghinorum, which is a fragmentary skull that lacks the anterior portion (Fig. 6E).

In dorsal view (Fig. 8A), the nasals are wide and slightly dorsally convex, and the anterior margin is pointed. The lateral margins of the frontals are damaged but the beginning of the anterior margin of the orbit can be seen on the left side. The middle suture of the temporals has a conspicuous crest in the posterior region. The posterior margin of the skull is very sharp with a marked crest formed by the occipitals.

In lateral view (Fig. 8B), the premaxilla is deformed and broken and the ascendant ramus is wide but does not surpass the naso-frontal suture. The masseteric fossa is deformed and broken; it is anteriorly formed by the premaxilla and posteriorly by the maxilla. It has a longitudinal furrow more or less parallel to the margin of the masseteric arch; this arch is anteroposteriorly elongated. The anterior ramus of the zygomatic arch begins anterior to the P4. Only the dorsal root of the maxillary zygomatic process is preserved and is relatively wide. In the orbital region, the maxilla is posteriorly broken and deformed, but similar in length to the maxillary orbital portion of Cardiomys ameghinorum. The squamosal is broad and extends posteriorly forming a downward curve, covering the ectotympanic. The ectotympanic is relatively small, with the auditory meatus opened posteriorly. Occipitals are oblique, projecting anteriorly downward.

In ventral view (Fig. 8C, E), the palate is relatively flat; the palatine foramina are elongated from the posterior margin of the M2, merging at the level of P4; the tooth rows are slightly convergent. Diastema length is approximately equal to the combined length of P4-M3 (30 mm). The rostrum width in front of the anterior root of the zygomatic arch is $16 \mathrm{~mm}$, half the width between both M3 $(30 \mathrm{~mm})$. The base of the anterior ramus of the zygomatic arch is posterolaterally oriented. The suture between maxilla and palatine runs from the posterior margin of the posterior palatine foramen toward the alveolar margin of M3, where it cannot be clearly seen because of a fracture. The mesopterygoid fossa is triangular in shape, with the middle anterior point at the level of prII of M3.

Mandible. The dentary (Fig. 8D, F, G) is robust and the nMpi is placed between $\mathrm{p} 4$ and $\mathrm{m} 1$ below the alveolar line; it is large and forms a continuous and thick border that extends from the anterior margin of the $\mathrm{p} 4$ ascending posteriorly, similar to other 'cardiomyines'. The mental foramen is located anterior to $\mathrm{p} 4$ and at the dorsoventral midpoint of the lateral surface of the dentary; it opens laterally (Fig. 8F).

Dentition. In Cardiomys the prisms of all molariforms are heartshaped, with the anteroposterior diameter proportionally long, the accessory fissures are relatively shallow and displaced toward c2, and M3 has four prisms plus a blunt posterior extension.

Upper teeth. P4-M2 bilobed with very shallow HPE and HSE penetrating less than $10 \%$ of the width of the prism, but the HSE seems to be deeper because of the labial extension of c1; both HPE and HSE are located toward the middle of the tooth, i.e. close to $\mathrm{c} 2$.

M3 has four prisms, the posterior one with a conspicuous posterior projection; prI similar to that of the other cheek teeth; prII with the labial side straight, depressed (Figs 8C, E; 9A, B).

Lower teeth. The $\mathrm{p} 4$ has three prisms, prI being very characteristic of the genus and different from that of Caviodon in which there is a single, relatively deep, hsi. In C. leufuensis this prI has the lingual margin convex, without hsi (Fig. 9CF). In C. ameghinorum (Fig. 9G, H), especially those specimens from the Santa María Valley (Catamarca), this margin is straight, depressed with respect to the lingual margin, and limited by two narrow and shallow fissures (Fig. 9G), which give a concave labial margin. The m1-3 are bilobed with hsi and hpi close to c2; hpi is deeper and wider than hsi (Figs 8D, 9C-F).

\section{Phylogenetic analysis}

The combined analysis resulted in a total of 37224 MPTs of 3290 steps, and a strict consensus of all trees was calculated (Pérez et al. 2017b). Hydrochoerinae is a monophyletic group; however, it shows a basal polytomy due to the unstable fragmentary fossil taxon Allocavia chasicoense that takes different positions within this clade in the most parsimonious trees (MPTs). When the alternative positions of this species are ignored, the reduced consensus corroborates the paraphyly of 'cardiomyines' that are shown as basal forms of Hydrochoerinae (Fig. 10), and retrieves Kerodon rupestris, Cardiomys? andinus and 


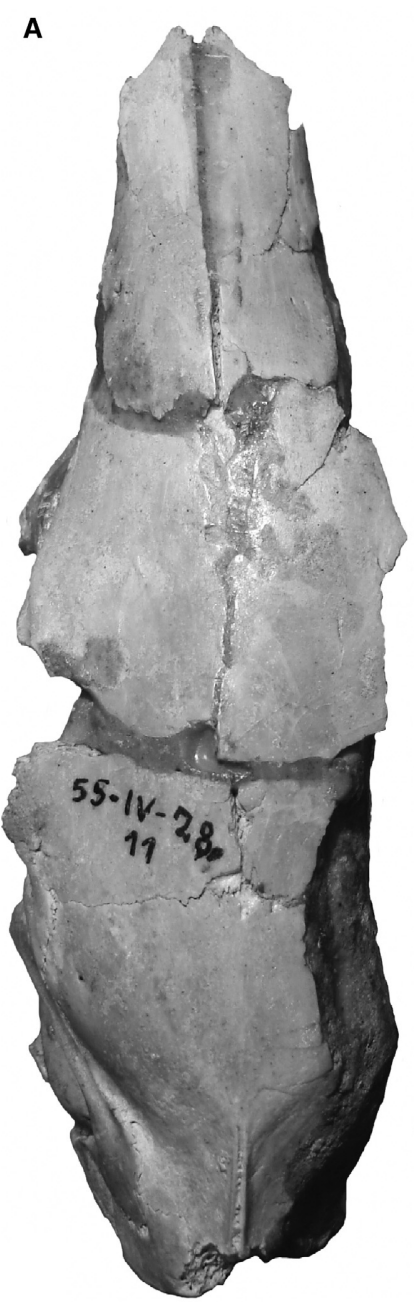

B

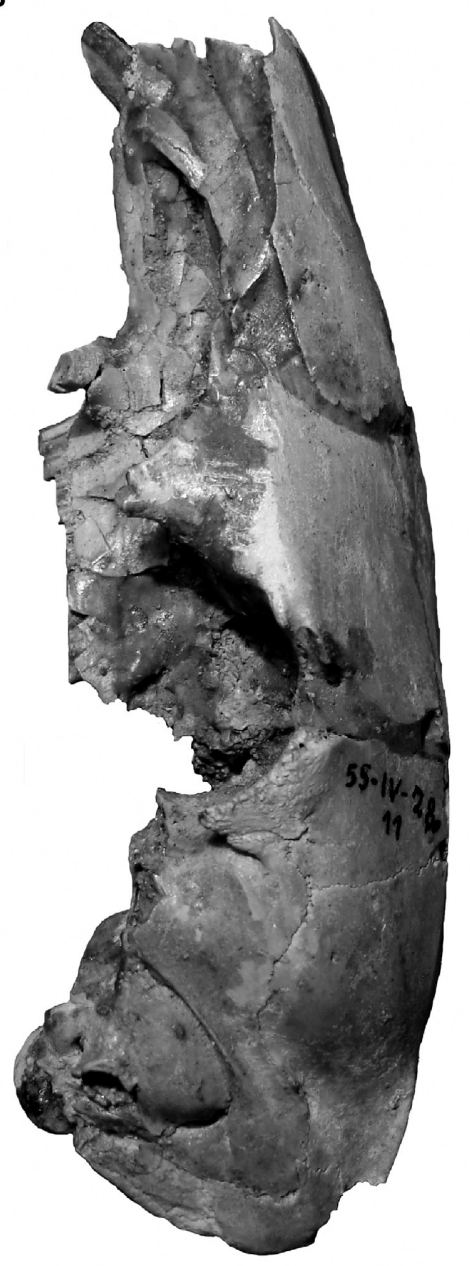

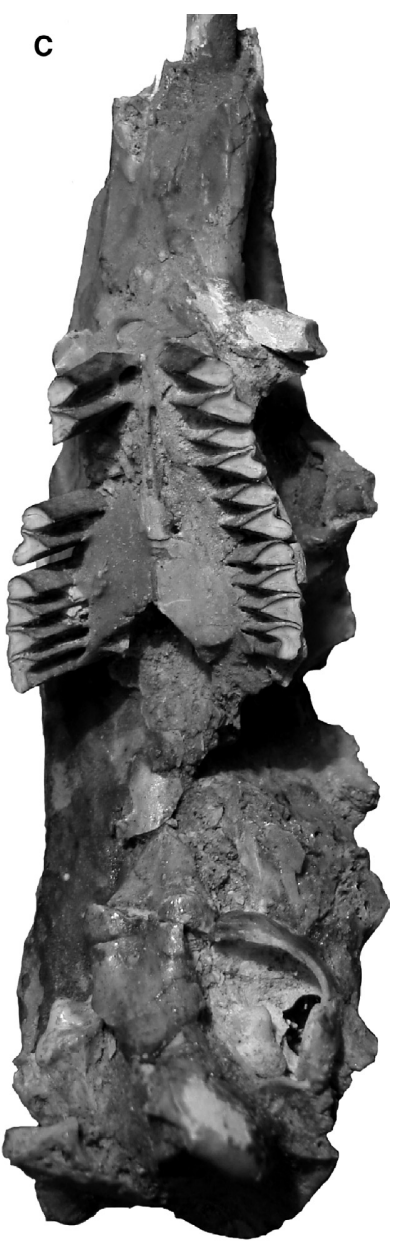
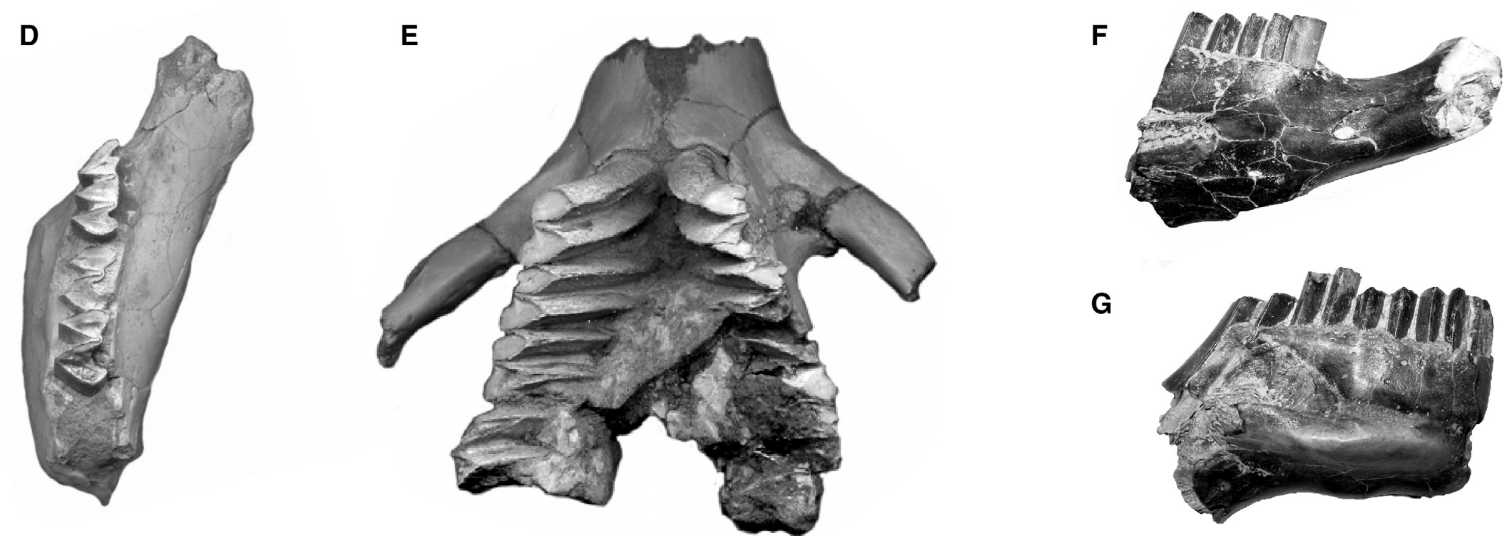

G

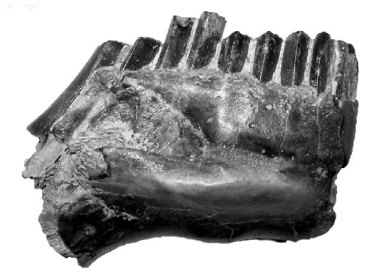

FIG. 8. Cardiomys leufuensis sp. nov. A-C, MLP 55-IV-28-11, skull: A, dorsal; B, lateral; C, ventral view. D, MLP 76-VI-12-92, left mandible fragment in occlusal view, with p4-m2. E, MLP 92-XI-19-19, skull fragment in ventral view, with right P4-M2 and fragment of M3 and left P4-M2. F, MLP 76-VI-12-18a, left mandible fragment in labial view with diastema and p4-m1 (reversed). G, MLP 76VI-12-18b, right mandible fragment in labial view with p4-m3. Scale bar represents $20 \mathrm{~mm}$. 
A

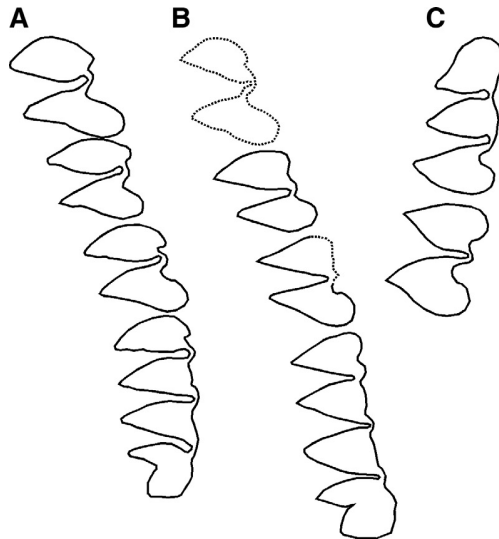

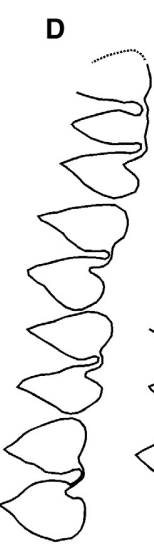

$\mathrm{E}$

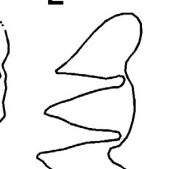

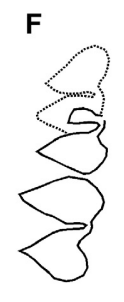

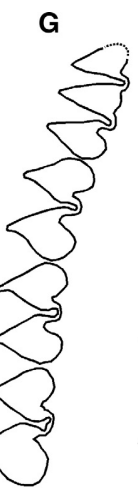

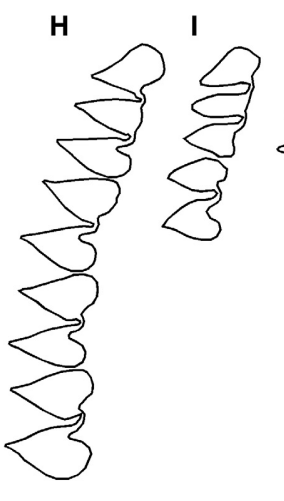

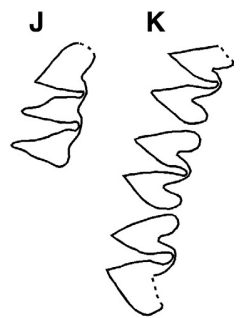

FIG. 9. Occlusal schemes of left dental series of the species of Cardiomys. A-B, upper teeth. C-K, lower teeth. A, C-F, Cardiomys leufuensis sp. nov. B, G-H, Cardiomys ameghinorum. I, Cardiomys mesopotamicus. J-K, Cardiomys cavinus. A, MLP 55-IV-28-11 (holotype), left P4-M3. B, MACN-Pv 8246 (holotype), left P4-M3. C, MLP 76-VI-12-18a, left p4-m1. D, MLP 76-VI-12-18b, right p4-m3 (reversed). E, MLP 76-VI-12-92, left p4-m2. F, MLP 92-XI-19-4, left p4-m1 (reversed; broken p4). G, MACN-Pv 8247, left p4-m3. H, MACN-Pv 8538 (holotype of C. ameghinorum var. latidens) right p4-m3 (reversed). I, MACN-Pv 3832, left p4-m1. J, MLP M 28, cast of the holotype of Cardiomys cavinus (the original is lost); MACN-Pv 4593, right mandible with m1-3 (reversed). Scale bar represents $10 \mathrm{~mm}$.

Procardiomys martinoi as the most basal forms of Hydrochoerinae. Support analyses (Fig. 10) yielded low values (both Bremer support and bootstrap) because of the low resolution of the basal forms within Hydrochoerinae.

Hydrochoerinae (Fig. 10, node A) is supported by eight morphological unambiguous synapomorphies: character 8 [state 1]: medial edge of the condyle, that is the insertion point of $m$. pterygoideus externus in posterior view, poorly developed projecting medially forming a small knob with respect to the medial wall of the dentary; ch. 20 [3]: the root of the lower incisors extending up to the level of the posterior lobe ofm1; ch. 45 [1]: anteroposterior length of incisive foramina, short; ch. 53 [0]: position of the boundary between the mastoid and paraoccipital processes at the same level or above the external auditory meatus; ch. 77 [3]: p4 with prsa; ch. 94 [1]: presence of hse in p4; ch. 100 [1]: presence of hsi in $\mathrm{m} 1-\mathrm{m} 2$; ch. 122 [1]: presence of HPE in M1-M2. Additionally, 36 molecular data are shared between Kerodon rupestris and Hydrochoerus hydrochaeris.

The basal position of Kerodon rupestris, Cardiomys? andinus and Procardiomys martinoi, arises because they lack derived characters such as more than three prisms in $\mathrm{M} 3$, or deeper fissures in $\mathrm{p} 4$. The $\mathrm{p} 4$ of $K$. rupestris has three prisms (a derived character within Caviidae); however, this tooth has very shallow fissures. Moreover, Kerodon has only two prisms in M3, which is a plesiomorphic character for this group. Cardiomys? andinus has only one lower molar with very shallow hpi and hsi and with heart-shaped prisms. Procardiomys martinoi presents only three prisms in $\mathrm{M} 3$, in contrast with the condition of more derived Hydrochoerinae, in which the M3 has more than three prisms.
Cardiomys ameghinorum, C. leufuensis, and the lineage that leads to the other hydrochoerines are placed in a more derived position (Fig. 10, node B). The basal position of these taxa with respect to Xenocardia, Caviodon, Cardiatherium and more derived hydrochoerines, is supported by ten morphological unambiguous synapomorphies: ch. 70 [0]: absence of constriction of the apex in each prism of molars; ch. 21 [0]: nMpi with respect to the toothrow, located between $\mathrm{p} 4$ and $\mathrm{ml}$; ch. 26 [0]: dorsoventral length of the scar, high; ch. 31 [1]: posterior extension of the horizontal crest, in lateral view, approximately ending at the anteroposterior midpoint of the mandibular condyle; ch. 37 [1]: anteroposterior length of the upper diastema, shorter than molariform series; ch. 41 [1]: apex of mesopterygoid fossa, curved; ch. 46 [0]: palate plane; ch. 89 [1]: presence of h5i in prsa of p4; ch. 108 [1]: depth of hpi in $\mathrm{m} 2$ up to $25 \%$ of the occlusal surface; ch. 126 [3]: four prisms in M3.

A polytomy in a more derived position (Fig. 10, node C) includes Xenocardia diversidens, Cardiomys cavinus, Caviodon multiplicatus, C. australis, C. pozzi, C. cuyano, C. andalhualensis, and the clade of Cardiatherium and more derived Hydrocherinae. The 12 unambiguous synapomorphies that support this group are: ch. 42 [1]: margins of the mesopterygoid fossa, parallel; ch. 80 [23]: depth of hpi in p4 25-50\%; ch. 84 [1]: presence of h3i (hsia) or hsi in p4; ch. 90 [1]: depth of h5i in prsa in p4, up to $50 \%$; ch. 91 [1]: depth of hpi with respect to h5i, equally deep; ch. 101 [12]: depth of hsi in $\mathrm{m} 1-\mathrm{m} 2$, less than 50\%, approximately half of the prism (50\%); ch. 107 [0]: depth of hsi respect to hpi in $\mathrm{m} 1$, equally deep; ch. 108 [2]: depth of hpi in $\mathrm{m} 2$, up to $50 \%$; ch. 124 [0]: depth of HPE respect to HSE, equally deep; ch. 125 [3]: 


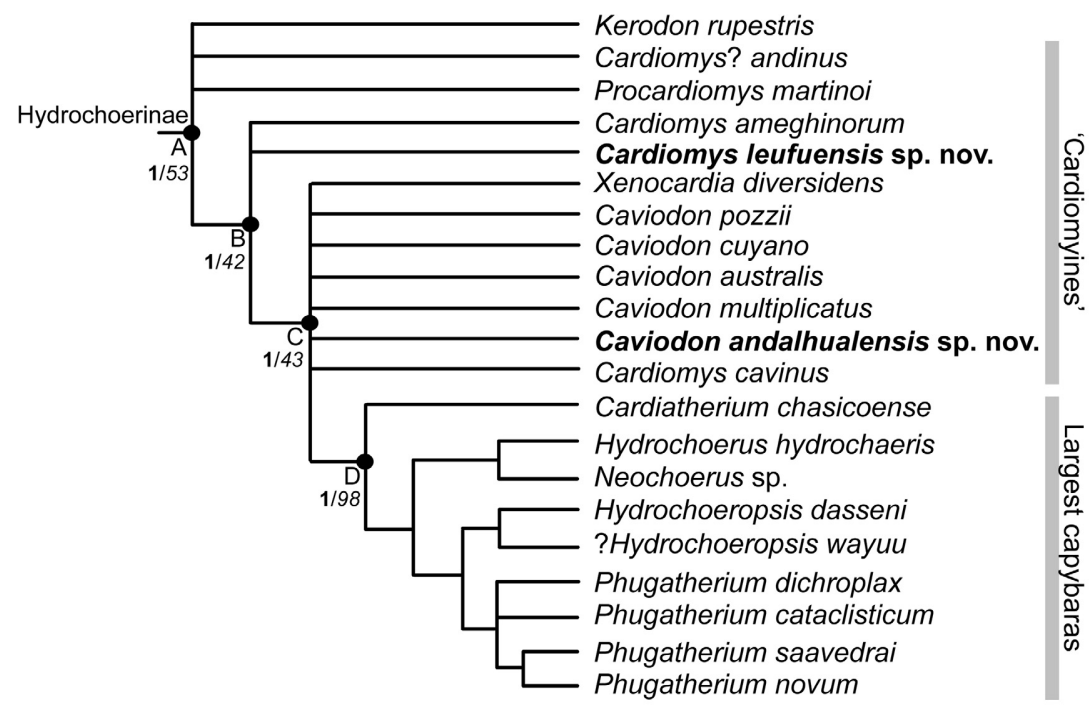

FIG. 10. Reduced strict consensus of Hydrochoerinae (Node A), ignoring the unstable fossil taxon Allocavia chasicoense. 'Cardiomyines' is a paraphyletic group and includes the most basal forms among Hydrochoerinae. Upper case letters indicate the nodes within Hydrochoerinae. The numbers in bold indicate Bremer support values, those in italics represent bootstrap values.

P4>M1>M2; ch. 126 [4]: 5-6 lobes in M3; ch. 127 [1]: lobes in M3 lanceolate shaped (with three or more prisms, in which the first ones is/are heart-shaped). A discussion about the position of Xenocardia and Cardiomys cavinus is provided below.

The clade of Cardiatherium and more derived hydrochoerines (i.e. Phugatherium, Hydrochoeropsis, Neochoerus and Hydrochoerus) is supported by 21 morphological synapomorphies (see Pérez et al. 2017b).

\section{DISCUSSION}

\section{Systematic considerations}

Taxonomic and phylogenetic analyses of the species traditionally considered to be 'cardiomyines' corroborate the paraphyly of these forms, which are the most basal among Hydrochoerinae, and the following considerations arise.

The species of Caviodon described from the Conglomerado osífero of the Ituzaingó Formation (C. paranensis, C. angustidens and C. scalai) are here synonymized with Caviodon multiplicatus because all the remains of this genus are considered to pertain to different ontogenetic stages of a single species. The material of Caviodon shows a progressive increase in deepening of the fissures and addition of prisms to the M3 from the oldest (C. andalhualensis and C. multiplicatus) toward the youngest species (C. pozzi and C. cuyano).

Cardiomys cavinus and C. vignatii from the Conglomerado osífero deserve further study. The metatype (Kraglievich 1932) of the type species (Cardiomys cavinus) consists in a hemimandible fragment with $\mathrm{m} 1-\mathrm{m} 3$ (Fig. 9K), which has relatively deep hpi and hsi, equal in depth near the middle of the prism (which are diagnostic characters of Caviodon). The phylogenetic analysis indicates a more derived position for Cardiomys cavinus with respect to the other Cardiomys species, probably more closely related to Caviodon; however, the resolution in the cladistical analysis is poor (Fig. 10, Node C). Cardiomys vignatii has narrower prisms than other species of Cardiomys, and the M3 has five prisms, not four as is typical of Cardiomys. Here, we maintain Cardiomys cavinus and C. vignatii within Cardiomys, pending the discovery of new and more complete material from the Conglomerado osífero that would allow a more thorough taxonomic analysis.

The holotype of Cardiomys intermedius is lost; hence, although the original description coincides with the morphology of C. mesopotamicus, their synonymy cannot be confirmed.

Allocavia chasicoense is a species represented by a single specimen, a right maxillary fragment with $\mathrm{P} 4-\mathrm{M} 1$; in the phylogeny it takes different alternative positions within Hydrochoerinae. The AP of its molariforms is $4 \mathrm{~mm}$, and the HPE and HSE are very shallow, especially the HPE. Following the proposal of ontogenetic change for capybaras proposed by Vucetich et al. (2005), it cannot be rejected that this specimen (and taxon) represents a juvenile of C. leufuensis or alternatively Procardiomys martinoi, the two 'cardiomyines' found in the Arroyo Chasicó Formation.

Xenocardia diversidens consists of a fragmentary maxilla and palate with both molariform series. This taxon is similar to Caviodon because its M3 has five prisms plus a posterior projection, narrow prisms with HPE and HSE relatively deep (typical of Caviodon). In our phylogenetic analysis, $X$. diversidens collapses with the species of Caviodon. Although the resolution is low, $X$. diversidens seems to be closely related to Caviodon.

The most important features that allow differentiation of the new material assigned to Caviodon andalhualensis from Cardiomys ameghinorum, to which it was previously referred, are the $\mathrm{p} 4$ with a deep and single hsi in prI, the 
M3 with six prisms plus a small posterior projection, relatively deep fissures (and equally deep) in the middle of the prisms and in all molariforms, wider palatine rami, and rounded shape of the mesopterygoid fossa (Figs 4C, 6, 8C). Instead, in C. ameghinorum the $\mathrm{p} 4$ has two very shallow fissures in prI next to columns c2 and c4, the M3 has four prisms and a thick posterior projection, all of them without fissures, shallow fissures in all molariforms and toward c2, the palatine rami are thinner, and the mesopterygoid fossa is ogival (Figs 6, 7).

This review brings up again the issue of the boundary between Cardiomys and Caviodon because the m1-m3 of some isolated jaws from the Andalhuala Formation have internal fissures with intermediate depth, position in the prism, and relative development to each other. Riggs \& Patterson (1939) did not recognize Caviodon as a distinct genus, but commented about materials that were similar to the 'Lelongia type' (= Caviodon (Lelongia)) of Kraglievich (1932). It is very likely that they were considering the materials FMNH P 14457, P 14434 and P 15287, here assigned to Caviodon andalhualensis. Later, Marshall \& Patterson (1981) recognized only the species Cardiomys ameghinorum among the 'cardiomyines' of Catamarca. However, our revision of this material housed in the Field Museum showed that the only specimens that can be assigned to Cardiomys ameghinorum are FMNH P 15251, P 15298 and P 14513, while the other three specimens (FMNH P 14457, $\mathrm{P} 14434$ and $\mathrm{P}$ 15287) represent $C$. andalhualensis and the first reports of Caviodon for the Andalhuala Formation.

'Cardiomyinae Genus and Species Indeterminate A' from Western Amazonia (Frailey 1986) is a Dolichotinae because M1 or M2 have double heart-shaped lobes, dentine crest, a furrow opposite the HFI (hypoflexus), with HPE and HSE absent; and 'Cardiomyinae Genus and Species Indeterminate B' is a Neoepiblemyidae because of the straight and parallel lobes with a wide cement layer in the hypoflexus.

\section{Diversity}

The modern diversity of hydrochoerines is very low, represented by two species of the gigantic semiaquatic capybaras (Hydrochoerus hydrochaeris and H. isthmius, the most derived living Hydrochoerinae) and two small rocky cavies (Kerodon rupestris and K. acrobata, the most basal in the clade). However, in the past hydrochoerines were more diverse, in part because of the presence of 'cardiomyines'. Their acme is recorded in the late Miocene ( 7 species of the capybara Cardiatherium, and 11 'cardiomyines': 6 species of Cardiomys, 1 of Xenocardia, 1 of Procardiomys, and at least 3 of Caviodon). They declined in the Pliocene when Cardiomys became extinct, Caviodon was restricted to three species (Fig. 2), and the largest capybaras were represented by four species of Phugatherium and two species of Hydrochoeropsis. In the Pleistocene, 'cardiomyines' became extinct and hydrochoerines were restricted to the extinct Neochoerus, and the living Hydrochoerus and Kerodon (Vucetich et al. 2012, 2015; Pérez et al. 2017a).

\section{Biogeography}

This revision raises some points concerning the geographical distribution of the 'cardiomyines'. Although the geographical distribution of most genera overlaps at mid latitudes, they show some differences. Only basal 'cardiomyines' (Cardiomys, Cardiomys? and Procardiomys) have been recorded at high latitudes during the middle to early late Miocene (Mayoan-Chasicoan SALMAs), Chubut (Fig. 1,12) and southern Buenos Aires province (Fig. 1, 10), and Cardiomys in particular is also recorded in mid latitudes during the Huayquerian, Mendoza (Fig. 1, 2), Catamarca (Fig. 1, 4), Entre Ríos (Fig. 1, 5), La Pampa (Fig. 1, 9) and San Juan (Fig. 1, 11) provinces. Instead, the more derived Caviodon and Xenocardia, are first recorded at low/mid latitudes, western Amazonia (Fig. 1, 6), San Juan (Fig. 1, 11), Catamarca (Fig. 1, 4) and Entre Ríos (Fig. 1, 5) provinces, and only in the Pliocene at higher latitudes, southern Mendoza (Fig. 1, 2) and Buenos Aires (Fig. 1, 1, 1,3) provinces. This distribution suggests that Caviodon could originated in mid or low latitudes, and later migrated southward.

\section{CONCLUSIONS}

The diversity of Hydrochoerinae in the past was much higher than at present; however, the oldest forms remain poorly known. Here the taxonomic diversity of 'cardiomyines' is enlarged and a phylogenetic analysis corroborates the paraphyly of these forms. Two new 'cardiomyine' species are recognized for the late Miocene: Caviodon andalhualensis (from the Huayquerian of Catamarca Province) and Cardiomys leufuensis (from the Chasicoan of Buenos Aires Province). C. andalhualensis represents the first Caviodon recognized for the Andalhuala Formation, while Cardiomys leufuensis is the first Cardiomys formally reported from the Arroyo Chasicó Formation. Revision of Caviodon suggests that only one species of this genus, the type species Caviodon multiplicatus, is valid for the material found in the Conglomerado osífero. Our taxonomic and phylogenetic analyses indicate that Xenocardia diversidens is more closely related to Caviodon than to Cardiomys.

The geographical and temporal distribution shows that two 'cardiomyine' genera and species (Cardiomys leufuensis and Procardiomys martinoi) occur in the Arroyo Chasicó 
Formation, while Allocavia chasicoense may be a juvenile of one of these two. The record of the genus Cardiomys is restricted to the late Miocene, whereas that of Caviodon spans from the late Miocene to the Pliocene. Cardiomys was restricted to southern South America whereas Caviodon was found also in western Amazonia and Venezuela.

Acknowledgements. The authors especially thank K. Angielczyk and W. Simpson (FMNH), M. Reguero (MLP), A. Kramarz (MACN-Pv), and the late A. Dondas (MMP) for access to the collections in their care. We also thank Lionel Hautier (Editor of Papers in Palaeontology) and Sally Thomas (Palaeontological Association), as well as Myriam Boivin and Phillip Cox, who provided formal reviews of this manuscript that improved the final version. This research was partially supported by PICT 2010-2613 (MEP) and PICT 1483-2012 (MGV and MEP).

\section{DATA ARCHIVING STATEMENT}

This published work, and the nomenclatural acts it contains, have been registered in ZooBank: http://zoobank.org/References/CFDB051DFA79-4EA1-8A07-4621CABEEBE9

Data for this study are available in the Dryad Digital Repository: https://doi.org/10.5061/dryad.pj562

Editor. Lionel Hautier

\section{REFERENCES}

AMEGHiNO, F. 1885. Nuevos restos de mamíferos fósiles oligocenos recogidos por el Profesor Pedro Scalabrini y pertenecientes al Museo Provincial de la ciudad del Paraná. Boletín de la Academia Nacional de Ciencias, 8, 5-207.

— 1888. Lista de especies de mamíferos fósiles del Mioceno Superior de Monte Hermoso, hasta ahora conocidas. P. E. Coni e hijos, Buenos Aires, 1-21.

— 1889. Contribución al conocimiento de los mamíferos fósiles de la República Argentina. Actas de la Academia Nacional de Ciencias en Córdoba, 6, 1-1027.

BOWDICH, T. E. 1821. An analysis of the natural classifications of Mammalia for the use of students and travellers. Smith, Paris.

BUTLER, R., MARSHALL, L., DRAKE, R. and CURTIS, G. 1984. Magnetic polarity stratigraphy and ${ }^{40} \mathrm{~K}-{ }^{40}$ Ar dating of Late Miocene and Early Pliocene continental deposits, Catamarca Province, NW Argentina. Journal of Geology, 92, 623-636.

CIONE, A. L., AZPELICUETA, M. M., BOND, M., CARLini, A. A., CASCIOTTA, J., COZZUOL, M., DE LA FUENTE, M. S., GASPARINI, Z., GOIN, F., NORIEGA, J., SCILLATO-YANÉ, G., SOIBELZON, L., TONNI, E. P., VERZI, D. and VUCETICH, M. G. 2000. Miocene vertebrates from Entre Ríos, eastern Argentina. 191-237. In AZEÑOLAZA, F. and HERBST, R. (eds). El Mio-Plioceno Argentino. Serie de Correlación Geológica, 14, INSUGEO.

DAL MOLIN, C. and FRANCHI, M. 1996. Reinterpretación estratigráfica de las Sedimentitas Terciarias del Sudoeste de Chubut. Actas XIII Congreso Geológico Argentino, 1, 473-478.
DESCHAMPS, C. M., VUCETICH, M. G., MONTALVO, C. I. and ZÁRA TE, M. A. 2013. Capybaras (Rodentia, Hydrochoeridae, Hydrochoerinae) and their bearing in the calibration of the late Miocene-Pliocene sequences of South America. Journal of South American Earth Sciences, 48, 145-158.

DUNNUM, J. L. 2015. Family Caviidae. 690-726. In PATTON, J. L., PARDIÑAS, U. F. J. and D'ELÍA, G. (eds). Mammals of South America. Vol 2, Rodents. University of Chicago Press.

ESTEBAN, G., NASIF, N. and GEORGIEFF, S. M. 2014. Cronobioestratigrafía del Mioceno tardío - Plioceno temprano, Puerta de Corral Quemado y Villavil, provincia de Catamarca, Argentina. Acta Geológica Lilloana, 26, 165-192.

FISCHER DE WALDHEIM, G. 1817. Adversaria zoologica. Mémoires de la Societé Imperiale des Naturalistes de Moscou, 5, 357-428.

Folguera, A. and ZÁrAte, M. A. 2009. La sedimentación neógena continental en el sector extrandino de Argentina central. Revista de la Asociación Geológica Argentina, 64, 692-712.

FRAILEY, C. D. 1986. Late Miocene and Holocene mammals, exclusive of the Notoungulata, of the Río Acre Region, Western Amazonia. Contributions in Science, Natural History Museum of Los Angeles County, 374, 1-46.

GARRIDO, A. C., TURAZZINI, G. F., BOND, M., AGUirrezABALA, G. and FOrAsiepi, A. M. 2014. Estratigrafía, vertebrados fósiles y evolución tectosedimentaria de los depósitos neógenos del Bloque de San Rafael (MiocenoPlioceno), Mendoza, Argentina. Acta Geológica Lilloana, 26, $133-164$.

GOLOBOFF, P., FARRIS, J. and NIXON, K. 2008a. TNT: Tree analysis using new technology, version 1.1 (Willi Hennig Society Edition). http://www.zmuc.dk/public/phylogeny/tnt 2008b. A free program for phylogenetic analysis. Cladistics 24, 774-776.

GRAY, J. E. 1825. An outline of an attempt at the disposition of the Mammalia into tribes and families with a list of the genera apparently appertaining to each tribe. Annals of Philosophy (new series), 10, 337-344.

KERBER, L., RIBEIRO, A. M., NASIF, N. and FERIGOLO, J. 2017. Tropical fossil Caviomorph rodents from the Southwestern Brazilian Amazonia in the context of the South American: systematics, biochronology, and paleobiogeography. Journal of Mammalian Evolution, 24, 57-70.

KRAGLIEVICH, L. 1927. Nota preliminar sobre nuevos géneros y especies de roedores de la fauna Argentina. Physis, 8, 591-598.

1930. La Formación Friasiana del río Frías, río Fénix, laguna Blanca, etc., y su fauna de mamíferos. Physis, 10, 127-161.

1932. Diagnosis de nuevos géneros y especies de roedores cávidos y eumegámidos fósiles de la Argentina. Rectificación genérica de algunas especies conocidas y adiciones al conocimiento de otras. Anales de la Sociedad Científica Argentina, 114, 155-181.

LATORRE, C., QUADE, J. and McINTOCH, W. C. 1997. The expansion of the $\mathrm{C} 4$ grasses and global changes in the Late Miocene: stable isotope evidence from the America. Earth \& Planetary Science Letters, 146, 83-96. 
MARES, M. A. and OJEDA, R. A. 1982. Patterns of diversity and adaptation in South American Hystricognath rodents. 393-432. In MARES, M. A. and GENOWAYS, H. H. (eds). Mammalian biology in South America. Special Publication Series Pymatuning Laboratory of Ecology, 6, University of Pittsburgh, USA.

MARSHALL, L. G. and PATTERSON, B. 1981. Geology and geochronology of the mammal-bearing Tertiary of the Valle de Santa María and Corral Quemado, Catamarca Province, Argentina. Fieldiana Geology, 9, 1-80.

DRAKE, R. E. and CURTISS, G. H. $1986 .{ }^{40} \mathrm{~K}-{ }^{40} \mathrm{Ar}$ calibration of Late Miocene-Pliocene Mammal-bearing Huayquerías and Tunuyán formations, Mendoza Province, Argentina. Journal of Paleontology, 60, 448-457. Tulsa.

MILANA, J. P., BERCOWSKI, F. and JORDAN, T. 2003. Paleoambientes y magnetoestratigrafía del Neógeno de la Sierra de Mogna, y su relación con la Cuenca de Antepaís Andina. Revista de la Asociación Geológica Argentina, 58, 447-473.

MONES, A. 1991. Monografía de la familia Hydrochoeridae (Mammalia, Rodentia): sistemática-paleontología-bibliografía. Courier Forschungsinstitut Senckenberg, 134, 1-235.

PASCUAL, R. 1961. Un nuevo Cardiomyinae (Rodentia, Caviidae) de la Formación Arroyo Chasicó (Plioceno inferior) de la provincia de Buenos Aires. Ameghiniana, 2, 61-72.

_ and BONDESIO, P. 1963. Un nuevo tipo de morfología dentaria en un Cardiatheriinae (Rodentia, Hydrochoeridae) del Plioceno inferior de Huachipampa (San Juan). Ameghiniana, 3, 43-49.

- ORtega Hinojosa, E. J., GONDAR, D. and TONNI, E. P. 1966. Paleontografía Bonaerense. Fascículo IV. Vertebrata. Comisión de Investigaciones Científicas de la Provincia de Buenos Aires, 202 pp.

PÉREZ, M. E. 2010. A new rodent (Cavioidea, Hystricognathi) from the middle Miocene of Patagonia, mandibular homologies, and the origin of the crown group Cavioidea sensu stricto. Journal of Vertebrate Paleontology, 30, 1848-1859.

_ and VUCETICH, M. G. 2011. A new exctinct genus of Cavioidea (Rodentia, Hystricognathi) from the Miocene of Patagonia and the evolution of cavioid mandibular morphology. Journal of Mammalian Evolution, 18, 163-183.

— $—$ and DESCHAMPS C. M. 2014. Mandibular remains of Procardiomys martinoi Pascual, 1961 (Hystricognathi, Cavioidea) from the Arroyo Chasicó Formation (early late Miocene) of Argentina, and the phylogenetic position of the genus within Caviidae. Historical Biology, 26, 16-25.

_ VAllejo-PARejA, M. C., CARrillo, J. D. and JARAMILLO, C. 2017a. First record of Pliocene capybaras (Rodentia, Caviidae) from La Guajira Peninsula, Northeastern Colombia, and its implications in the Great American Biotic Interchange. Journal of Mammalian Evolution, 24, 11-125.

- DESCHAMPS, C. M. and VUCETICH, M. G. $2017 b$. Data from: Diversity, phylogeny and biogeography of the South American 'cardiomyine' rodents (Hystricognathi, Cavioidea) with a description of two new species. Dryad Digital Repository. https://doi.org/10.5061/dryad.pj562

POL, D. and ESCAPA, I. H. 2009. Unstable taxa in cladistic analysis: identificationand the assessment of relevant characters. Cladistics, 25, 515-527.
POPESKO, P., RAJTOVÁ, V. and HORÁK, J. 2003. A colour atlas of anatomy of small laboratory animals. Vol. 1, Rabbit - Guinea Pig. 256 pp. Elsevier Health Sciences, Saunder.

RIGGS, E. S. and PATTERSON, B. 1939. Stratigraphy of Late Miocene and Pliocene deposits of the Province of Catamarca (Argentina) with notes on the faunae. Physis, 14, $143-162$.

ROVERETO, C. 1914. Los Estratos Araucanos y sus fósiles. Anales del Museo Nacional de Historia Natural, 25, 1-147.

ROWE, D. L. and HONEYCUTT, R. L. 2002. Phylogenetic relationships, ecological correlates, and molecular evolution within the Cavioidea (Mammalia, Rodentia). Molecular Biology \& Evolution, 19, 263-277.

RUSCONI, C. 1944. Especies nuevas de mamíferos del Puelchense de Buenos Aires. Boletín Paleontológico de Buenos Aires, $16,1-4$.

SCHALLER, O. (ed.) 2007. Illustrated veterinary anatomical nomenclature. 2nd edn. Enke, Stuttgart.

STORR, G. C. 1780. Prodromus methodi Mammalium inauguralem disputationem propositus. F. Wolffer, Tübingen, 1-43.

TOMASSINI, R. L., MONTALVO, C. I., DESCHAMPS, C. M. and MANERA, T. 2013. Biostratigraphy and biochronology of the Monte Hermoso Formation (early Pliocene) at its type locality, Buenos Aires Province, Argentina. Journal of South American Earth Sciences, 48, 31-42.

TONNI, E. P., PRADO, J. L., FIDALGO, F. and LAZA, J. H. 1992a. El Piso/Edad Montehermosense (Plioceno) y sus mamíferos. Acta Terceras Jornadas Geológicas Bonaerenses, $113-118$.

— Alberdi, M. T., PRADO, J. L., BARGO, M. S. and CIONE, A. L. 1992b. Changes of mammal assemblages in the Pampean Region (Argentina) and their relation with the Plio-Pleistocene boundary. Palaeoecology, Palaeogeography, Palaeoclimatology, 95, 179-194.

TUlLBERG, T. 1899. Uber das System der Nagethiere: eine phylogenetische Studie. Nova Acta Regiae Societatis Scientiarum Upsalensis, 3, 1-514.

VUCETICH, M. G. and PÉREZ, M. E. 2011. The putative cardiomyines (Rodentia, Cavioidea) of the middle Miocene of Patagonia (Argentina) and the differentiation of the Family Hydrochoeridae. Journal of Vertebrate Paleontology, 31, 13821386.

— and VERZI, D. H. 1995. Los Roedores Caviomorpha. 211-225. In ALBERDI, M. T., LEONE, G. and TONNI, E. P. (eds). Evolución Biológica y Climática de la Región Pampeana durante los últimos Cinco Millones de años. Monografías del Museo de Ciencias Naturales de Madrid, 12, Consejo Superior de Investigaciones Científicas, Madrid.

- DESCHAMPS, C. M., OLIVARES, A. I. and DOZO, M. T. 2005. Capybaras, shape, size and time: a model kit. Acta Paleontologica Polonica, 50, 259-272.

_ VieyTeS, E. C., PÉREZ, M. E. and CARLini, A. A. 2010. The rodents from La Cantera and the early evolution of caviomorphs in South America. 193-205. In MADDEN, R. H., CARLini, A. A., VUCETICH, M. G., and KAY, R. F. (eds). The paleontology of Gran Barranca: evolution and environmental change through the Middle Cenozoic of Patagonia. Cambridge University Press. 
DESCHAMPS, C. M., MORGAN, C. C. and FORASIEPI, A. 2011. A new species of Cardiomyinae (Rodentia, Hydrochoeridae) from western Argentina. Its age and considerations on ontogeny and diversity of the subfamily. Ameghiniana, 48, 556-567.

and PÉREZ M. E. 2012. Palaeontology, evolution and systematics of capybaras. 39-59. In MOREIRA, J. R., DE BARROS FERRAZ, K. M., HERRERA, E. A. and MACDONALD, D. W. (eds). Capybara: biology, use and conservation of an exceptional Neotropical species. Springer.

— ARNAL, M., DESChAMPS, C. M., PÉREZ, M. E. and VIEYTES, E. C. 2015. A brief history of caviomorph rodents as told by the fossil record. 11-62. In VASSALLO, A. and ANTONUCCI, D. (eds). Biology of caviomorph rodents; diversity and evolution. Sociedad Argentina para el estudio de los Mamíferos.
PÉREZ, M. E., ARNAL, M., DESCHAMPS, C. M. and VIEYTES, E. C. 2016. Caviomorph rodents: main features of their evolution. 347-358. In AGNOLIN, F. L., LIO, G. L., BRISSÓN EGLI, F., CHIMENTO, N. R. and NOVAS, F. E. (eds). Historia evolutiva y paleobiogeografica de los vertebrados de América del Sur. Contribuciones del Museo Argentino de Ciencias Naturales, 6.

WOODS, C. A. 1984. Hystricognath rodents. 389-446. In ANDERSON, S. and JONES, J. K. JR (eds). Orders and families of recent mammals of the world. Wiley.

— and HOWLAND, E. B. 1979. Adaptive radiation of capromyid rodents: anatomy of the masticatory apparatus. Journal of Mammalogy, 60, 95-116.

- and KILPATRICK, C. W. 2005. Infraorder Hystricognathi Brandt, 1855. 1538-1600. In WILSON, D. E. and REEDER, D. M. (eds). Mammal species of the world: a taxonomic and geographic reference. Johns Hopkins University Press.

\section{APPENDIX}

Material used in this study with their geographical and stratigraphical provenance.

Xenocardia diversidens Pascual \& Bondesio, 1963

Huachipampa, San Juan; Huachipampa Formation, early late Miocene: MLP 57-XII-23-5, skull fragment with damaged right and left P4-M3, holotype and single specimen.

\section{Procardiomys martinoi Pascual, 1961}

Arroyo Chasicó, Buenos Aires; Arroyo Chasicó Formation (= Cerro Azul Formation sensu Folguera \& Zárate 2009), early late Miocene: MMP 471-M, fragmentary palate with right and left P4M3 (holotype); MMH-CH-88-6-77, incomplete skull with right and left M1-M3; MLP 76-VI-12-143, fragmentary right and left mandibles with $\mathrm{p} 4-\mathrm{m} 3$; MMP 283-M, fragmentary left mandible with $\mathrm{p} 4-\mathrm{m} 1$; MMP 482-M, fragmentary left mandible with p4-m3.

\section{Caviodon multiplicatus Ameghino, 1885}

Paraná, Entre Ríos; Conglomerado osífero, Ituzaingó Formation: MACN-Pv 5891 isolated right M3 (holotype and single specimen); MACN-Pv 4495, left M3 (holotype and single specimen of Caviodon bravardi Kraglievich, 1927); MACN-Pv 13471, right M3 (holotype and single specimen of Caviodon (Lelongia) paranensis Kraglievich, 1930).

Caviodon australis (Ameghino, 1888) (including Caviodon obtritus Ameghino, 1888)

Farola Monte Hermoso, Buenos Aires; Monte Hermoso Formation, early Pliocene: MACN A-1657, fragment of left mandible and isolated molar fragment (see Rovereto 1914); MACN A1099, maxillary fragment with left P4 and isolated M3 (holotype of Diacartherium australe); MACN-Pv 7326, skull fragment with palate and both dental series; MACN-Pv 7526, skull fragment; MACN-Pv 14841, fragment of right mandible with m1-m2.
Caviodon pozzii Kraglievich, 1927

Chapadmalal, Buenos Aires; Chapadmalal Formation, early late Pliocene: MACN-Pv 6915, right jaw fragment with p4-m2 (holotype); MMP 525-M, skull with right P4-M3 and left M1M3; MLP 61-VII-10-8, left M3.

Caviodon cuyano Vucetich et al., 2011

Arroyo seco de la Frazada, Mendoza; middle section of the La Huertita Formation (Garrido et al. 2014; = SM of the Aisol Formation sensu Forasiepi et al. 2011), Pliocene?: MHNSR-PV 1101, large part of a deformed skull with left and right P4-M3, fragments of both jaws with left $\mathrm{p} 4, \mathrm{~m} 2-\mathrm{m} 3$ and right $\mathrm{p} 4-\mathrm{m} 3$, and postcranium (holotype and single specimen).

Caviodon andalhualensis sp. nov.

Valle de Santa María, Andalhuala Formation, Locality 4, Arroyo (= Río) de Yapes: FMNH P 14457 (assigned to Cardiomys ameghinorum by Marshall \& Patterson 1981), skull, atlas-axis and other vertebrae (holotype), level XX; FMNH P 14434, right jaw fragment with $\mathrm{p} 4-\mathrm{m} 2$, level 15-32 (above 19 in schedis); FMNH P 15287, left jaw fragment with p4 (no horizon).

\section{Caviodon sp.}

Paraná, Entre Ríos; Conglomerado osífero, Ituzaingó Formation: MLP 87-XI-1-12b, right p4; MLP 87-XI-1-11, right M3; MACN$\mathrm{Pv} 2483$, right m3; MACN-Pv 3410, left $\mathrm{m} 1$ or m2; MACN-Pv 13459, right mandible fragment with $\mathrm{p} 4-\mathrm{m} 3$ (the three latter are assigned in schedis to Cardiomys).

San Gregorio Formation, San Gregorio, Venezuela: UNEFMVF-53 (left M1 or M2) (Vucetich et al. 2010).

Solimões Formation, Patos locality, Acre River, Brazil: UFAC 5465 (M1 or M2) (Kerber et al. 2017).

\section{Cardiomyinae}

Paraná, Entre Ríos; Conglomerado osífero, Ituzaingó Formation: MACN-Pv 9033, right mandible fragment with p4-m3; MACNPv 17693, right mandible fragment with m1-m3; MLP 87-XI-1-4, 
isolated M1 or M2; MLP 87-XI-1-8, left jaw fragment with i, p4-m2; MLP 87-XI-1-20, right palatal fragment with M3.

\section{Cardiomys cavinus Ameghino, 1885}

Paraná, Entre Ríos, Conglomerado osífero, Ituzaingó Formation: MLP M 28: cast of the holotype, right p4; MACN Pv 4593, right jaw with m1-m3 (metatype).

Cardiomys mesopotamicus (Ameghino, 1885)

Paraná, Entre Ríos, Conglomerado osífero, Ituzaingó Formation: MACN-Pv 3832, fragment of left mandible with p4-m1 (holotype); MLP 52-X-1-84, right jaw fragment with $\mathrm{p} 4$ (damaged)$\mathrm{m} 3$.

Cardiomys leufuensis sp. nov.

Arroyo Chasicó, Buenos Aires; Arroyo Chasicó Formation (= Cerro Azul Formation sensu Folguera \& Zárate 2009), early late Miocene: MLP 55-IV-28-11, partial skull with right P4, M2M3 and left P4-M3 (holotype); MLP 92-XI 19-4, left mandible fragment with p4-m1, Vivero Member; MLP 92-XI-19-19, palate fragment with right $\mathrm{P} 4-\mathrm{M} 3$ and left $\mathrm{P} 4-\mathrm{M} 2$, and both anterior rami of the zygomatic arch, Las Barrancas Member; MLP 76-VI12-18, fragment of palate with right $\mathrm{P} 4-\mathrm{M} 1$ and left $\mathrm{P} 4$, right mandible fragment with $\mathrm{p} 4-\mathrm{m} 3$ and left mandible fragment with p4-m1, Las Barrancas Member, Bajada de los Toros; MLP 76VI-12-92, left mandible fragment with $\mathrm{p} 4-\mathrm{m} 2$, Las Barrancas Member, Quebrada del Hacha.

Cardiomys ameghinorum Rovereto, 1914

Andalhuala, Catamarca; Andalhuala Formation, late Miocene: MACN-Pv 8247, left jaw with p4-m3 (holotype); MACN-Pv 8246, skull without rostrum, with right and left P4-M3 partially damaged; MACN-Pv 8248, incomplete skull; MACN-Pv 4831, symphysis with both i-p4; MACN-Pv 8252, right palate fragment with M1-M2.

Puerta de Corral Quemado, Andalhuala Formation: FMNH P 15251 (no horizon), left mandibular fragment with $\mathrm{p} 4-\mathrm{m} 2$;
FMNH P 15298 (no horizon), left mandibular fragment with symphysis (in schedis assigned to Cardiomys ameghinorum latidens, but the material is not sufficient to make a definite assignment); FMNH P 14513 (level 20), partial skull with right M3 (in schedis assigned to Cardiomys ameghinorum var. latidens).

Cardiomys ameghinorum var. latidens Rovereto, 1914

Huayquerías de San Carlos, Mendoza; Huayquerías Formation, late Miocene; these levels were dated as $5.8 \pm 0.1 \mathrm{Ma}$ (Marshall et al. 1986): MACN-Pv 8538, right jaw with p4-m3 (holotype); MACN-Pv 8539, skull fragment with right P4-M3 and left P4, and both hemimandibles with incisors, right $\mathrm{p} 4-\mathrm{m} 2$ and left $\mathrm{p} 4$.

C. aff. ameghinorum

Paraná, Entre Ríos, Conglomerado osífero, Ituzaingó Formation: MACN-Pv 3823, right mandibular fragment with p4-m3.

\section{Cardiomys sp.}

Puerta de Corral Quemado, level 23: FMNH P 14491, right jaw with $\mathrm{p} 4-\mathrm{m} 3$; left jaw with $\mathrm{m} 1-\mathrm{m} 3$; femur, atlas, axis, ribs (in schedis Cardiomys ameghinorum var. latidens).

Valle de Santa María; Andalhuala Formation; Locality 1, Entre Ríos (= Chiquimil), level XVIIIb: FMNH P 14372 (assigned in schedis to Cardiomys; it was not mentioned by Marshall \& Patterson 1981), lower right dentition with $\mathrm{p} 4-\mathrm{m} 3$ and incisor fragment.

Puerta de Corral Quemado, El Jarillal Member of the Chiquimil Formation (Esteban et al. 2014), Catamarca, without other data: MACN-Pv 15313, right mandible fragment with p4-m3.

Conglomerado osífero, Ituzaingó Formation: MLP 41-XII-13178, left jaw with $\mathrm{p} 4-\mathrm{m} 2$.

Adolfo Alsina: MLP 49-XI-18-15, two isolated right m3.

Salinas de Hidalgo, Buenos Aires; Cerro Azul Formation (sensu Folguera \& Zárate 2009), late Miocene: MLP 65-VII-2989 , right jaw fragment with $\mathrm{p} 4$.

La Pampa Province, Conhelló (71 m depth): MACN-Pv 9612, left mandible fragment with $\mathrm{p} 4-\mathrm{m} 3$ and rostrum with both $\mathrm{P} 4$. 